\title{
Kärleksfullt tilltal, kvarsittning eller kroppsaga: En modellgenererande undersökning om korrektionsmedel i 1800-talets folkskolereglementen
}

\author{
David Sjögren
}

\begin{abstract}
Compassionate Corrections, Detention or Corporal Punishment: A Model-Generating Study on Correctional Methods in Nineteenth Century Comprehensive School Bylaws • This article aims to develop a systematising model to analyse correction and punishment in the nineteenth century elementary school in Sweden. The model is used to identify and compare the different forms of correction, to systematise mutual relationships between milder corrections and more harsh punishments, and to find patterns between faults and correction. The model is also used to systematically identify how expressions about correction and punishment change over time. The model is developed on the basis of normative material, which regulated how to maintain order in classrooms.
\end{abstract}

Keywords • elementary school [folkskola], conduct [uppförande], discipline [disciplin], punishment [straff]

Det svenska folkskoleväsendet expanderade kraftigt under 1800-talets andra hälft. Antalet barn inskrivna i fasta och ambulerande skolor flerdubblades, lärarkåren växte, skolbyggnader uppfördes över hela landet och ett allt mer finmaskigt nät av reglerande anvisningar om undervisningens innehåll och struktur utarbetades. Eftersom skolväsendet organiserades utifrån en lednings- och ansvarsstruktur som innebar att landets församlingar finansierade, ansvarade, ledde och skötte skolundervisningen i skoldistrikten, så skiftade skolväsendets utformning påtagligt distrikten emellan, vilket i sin tur hade demografiska, ekonomiska, sociala och kulturella orsaker. Över församlingarnas skolväsende reste sig efterhand en allt växande och alltmer detaljstyrande regional och nationell skolbyråkratisk överbyggnad med anvisande, reglerande och kontrollerande funktioner. Skolväsendet homogeniserades, standardiserades och utvecklades gradvis genom överbyggnadens olika funktioner. Massundervisningens framväxt, med skolutbildning som institutionell form, skapade naturligtvis en räcka nya förutsättningar och utmaningar för att bedriva undervisning. ${ }^{1}$

Utifrån detta fågelperspektiv på skolväsendets utveckling vill jag sammanföra två partikulära förändringstendenser under 1800-talets senare hälft. Den första tar fasta på folkskolans expansion som ledde till fler elever i allt större klasser, vilket i sin tur ställde andra, och möjligen större, krav på lärarnas uppgift att upprätthålla ordning och disciplin i skolan jämfört med tidigare. Den andra förändringstendensen tar fasta på skolväsendets homogeniserande utveckling som den framväxande byråkratiska överbyggnadens alltmer detaljstyrande ambitioner medförde. I artikeln

1 Se exempelvis Johannes Westberg, Att bygga ett skolväsen: Folkskolans förutsättningar och framväxt 1840-1900 (Lund: Nordic Academic Press, 2014), 20-24, 290-311.

David Sjögren is Associate Professor of History at the Department of Education, Uppsala University, Sweden. Email: david.sjogren@edu.uu.se 
sammanförs dessa förändringstendenser i en undersökning om skoldisciplinens lokala utformning och belyser de förändringar som denna utformning genomgår från folkskolans införande till 1800-talets slut.

Artikeln har till syfte att utveckla en användbar systematiserande modell för att analysera tillrättavisningar och bestraffningar i 1800-talets folkskola. Förhoppningen är att den systematiserande modellen skall komma till användning i kommande undersökningar. Modellen ska kunna användas för att identifiera och jämföra korrektionsmedlens olika former, systematisera inbördes förhållanden mellan mildare tillrättavisningar och strängare bestraffningar och finna mönster i koherenser mellan förseelseart och korrektionsform. Den kan också användas för att identifiera likheter och skillnader i olika utsagor om tillrättavisning och bestraffning samt hur dessa utsagor förändras över tid. Modellen utvecklas med utgångspunkt i normerande material, i det här sammanhanget folkskolereglementen, som reglerade hur tillrättavisning och bestraffning skulle gå till i klassrummen. Studien baseras på en närläsning av reglementenas paragraf om vad som skulle göras vid förseelser av olika slag.

\section{Tidigare forskning}

Mina motiv till att utveckla denna modell bygger i första hand på en avsaknad av systematisk analys av ett större material i tidigare svensk forskning. Enligt min mening har den sammantaget i allmänhet inte systematiskt analyserat normativt material och därmed inte uppmärksammat de mönster i utsagor som den här artikeln behandlar (nämligen korrektionsmedlens olika former, systematisering av olika typer av korrektionsformer, koherensmönster mellan förseelseart och korrektionsform). Jag skall drista mig till att förklara hur det kommer sig.

En huvudfåra inom forskning om uppfostran och synen på barndom har utgått ifrån Phillipe Ariès teser om att föreställningar om och begrepp för barndom, enkelt uttryckt, inte existerande förrän vid sekelskiftet 1800 och att barn disciplinerades hårt fram till dess. Vidare menar Ariès att kärlek till barn utvecklades, med början i de bildade klasserna, först under slutet av 1700-talet och därifrån spreds dessa uppfattningar till andra folklager. I efterföljd till dessa teser har exempelvis Llyod de Mause gått igenom 200 uppfostringsråd från antiken till 1600-talet och visat att endast ett fătal av dem innehöll avråd från kroppsbestraffning. ${ }^{2}$ Även svenska forskare som Ann-Sofie Ohlander och Birgit Persson har menat att barnuppfostran verkställdes med närmast övermått av våld. ${ }^{3}$ Christina Florin och Ulla Johansson menar att även folkskolans lärarkår frekvent gav eleverna slag, rapp och andra fysiska bestraffningar. ${ }^{4}$ Dessa utgångspunkter har dock ifrågasatts av en annan sida fors-

2 Llyod de Mause, red., The History of Childhood: The Evolution of Parent-Child Relationship as a Factor in History (London: Souvenir press, 1977); Llyod de Mause, The History of Childhood: The Untold Story of Child Abuse (London: Bellow, 1991).

3 Ann-Sofie Ohlander, Kärlek, död och frihet: Historiska uppsatser om människovärde och livsvillkor i Sverige (Stockholm: Nordstedts, 1985); Ann-Sofie Ohlander, Det bortträngda barnet: Uppsatser om psykoanalys och historia (Uppsala: Opuscula Historica Upsaliensia, 1993); Birgit Persson, "Aga och husliga bestraffningar," i Den utsatta familjen: Liv, arbete och samlevnad i olika nordiska miljöer under de senaste tvåhundra åren. En antologi från det Familjehistoriska projektet vid historiska institutionen, Uppsala universitet, red. Hans Norman (Stockholm: LT, 1983).

4 Christina Florin och Ulla Johansson, "Three Cultures, Three Stories: Discipline in Grammar School, Private Girls' School and Elementary Schools in Sweden, 1850-1900," i Discipline, Moral Regulation, and Schooling: A Social History, red. Kate Rousmaniere, Kari Dehli och Ning de Coninck-Smith (New York: Garland Publishing, 1997), 43-73, särsk 57-58. 
kare. ${ }^{5}$ De har i sin tur hävdat att kroppslig bestraffning visserligen tilläts, och ibland påbjöds, men att den sällan behövde användas. Bland annat har historikern Steven Ozment ansett att en negativ bild av äldre tiders uppfostran uppkommit genom en selektiv läsning av källmaterial. ${ }^{6}$ Bland svenska forskare har den omåttliga kroppsliga agan och avsaknaden av föräldrakärlek under tidigmoden tid ifrågasatts av bland andra Eva Österberg och Helena Brembeck. ${ }^{7}$ Min poäng är att Ariès teser, oavsett om man delar dem eller inte, har givit upphov till undersökningar om hur hård eller hur vanligt förekommande kroppslig bestraffning egentligen var. Därmed har andra tillrättavisnings- och bestraffningssätt fått liten uppmärksamhet och kroppsagans relation till andra korrektionsmedel behandlats i mindre utsträckning. I den något äldre svenska forskningen har undersökningsobjekt som aga i det närmaste varit synonyma med kroppslig bestraffning. ${ }^{8}$ En liknande tendens tycks finnas i den engelskspråkiga litteraturen. När man i denna undersöker och talar om "punishment" så är det ofta "corporal punishment" som är av särskilt intresse. ${ }^{9}$

Sedan något decennium har nya metodiska ansatser och nya perspektiv tillkommit i barndomshistorisk och utbildningshistorisk forskning. De nya ansatserna har riktat undersökningarna mot dagligt liv samt barns beskrivningar och erfarenheter av uppfostran och skola. ${ }^{10}$ John Deweys programförklaring "barnet i centrum" har tillämpats i själva forskningsansatserna. Perspektivförskjutningarna har medfört att barn inte enbart betraktats och beskrivits som offer för våld och bestraffningar, utan att de också tillskrivits funktioner som aktörer för att upprätthålla gränser mellan tillåten och otillåten bestraffning. ${ }^{11}$ Dessa nya ansatser har utvecklats parallellt med

5 Linda Pollock har gjort en genomgång av forskning som baseras på Ariès teser och också gått igenom sådan forskning som argumenterar emot Ariès. Linda Pollock, Forgotten Children: $\mathrm{Pa}$ rent-Child Relations from 1500 to 1900 (Cambridge: Cambridge University Press, 1983).

6 Steven Ozment, When Fathers Ruled: Family Lift in Reformation Europe (Cambridge Mass.: Harvard University Press, 1983).

7 Eva Österberg, Folk förr: Historiska essäer (Stockholm: Atlantis, 1995); Eva Österberg, "Barn i äldre tid - kulturhistoriska perspektiv," i Barnet i kyrkohistorien, red. Anders Jarlet (Lund: Lund University Press, 1998) s. 21-33; Helena Brembeck, Tyst, lydig, arbetsam: Om barnuppfostran på den västsvenska landsbygden (Göteborg: Etnologiska föreningen i Västsverige, 1986). Se även Eva Bergenlöv, Skuld och skam: Barnamord och barnkvävning i rättslig diskurs och praxis omkring 1680-1800 (Lund: Historiska institutionen, 2004), 388-91.

8 Exempelvis Persson (1983); Marianne Liliequist, Nybyggarbarn: Barnuppfostran bland nybyggare $i$ Frostvikens, Vilhelmina och Tärna socknar 1850-1920 (Umeå: Acta Universitatis Umensis, 1994).

9 Exempelvis Carles Sirera Miralles, "Enlightened Paternalism: The Prohibition of Corporal Punishment in Spanish Public Schools in the Nineteenth Century," History of Education 44, no. 2 (2015), 156-70; Frederik Herman et al., "Punishment as an Educational Technology: A Form of Pedagogical Inertia in Schools?," i Educational Research: Networks and Technologies, redaktör Paul Smeyers, Marc Depaepe (New York: Springer, 2007), 203-19.

10 Se exempelvis Jane Humphries, Childhood and Child Labour in the British Industrial Revolution (Cambridge: Cambridge University Press, 2010); Jane Humphries, "Childhood and Violence in Working-Class England 1899-1870," i Childhood and Violence in the Western Tradition, red. Laurence Brockliss och Heather Montgomery (Oxford: Oxbow books, 2010), 135-41; Colin Heywood, Growing up in France: From the Ancien Régime to the Third Republic (Cambridge: Cambridge University Press, 2007); Kate Rousmaniere, Kari Dehli och Ning de Coninck-Smith, "Conclusion: New Perspective on Moral Regulation and Schooling," i Discipline, Moral Regulation, and Schooling: A Social History, red. Kate Rousmaniere, Kari Dehli och Ning de Coninck-Smith (New York: Garland Publishing, 1997), 273-77.

11 Se exempelvis Laurence Brockliss och Heather Montgomery, "Preface," i Childhood and Violence in the Western Tradition, red. Laurence Brockliss och Heather Montgomery (Oxford: Oxbow books 2010), X. 
att nya typer av källmaterial har kommit i bruk. ${ }^{12}$ Självbiografier och dagböcker är i detta sammanhang två sådana viktiga materialtyper. Min avsikt är inte att redogöra för denna omfattande forskning, utan att poängtera att de nya materialtyperna medfört att forskningen ånyo uppmärksammat särskilt våldsamma former av uppfostran och bestraffning. Nyanseringar förekommer naturligtvis. Men rimligen uppehåller sig det självbiografiska materialet vid händelser som har fastnat i minnet beroende på de olustkänslor de frambringat eller på grund av att de skiljde sig från dagliga erfarenheter. Man minns, enkelt uttryckt, slaget bättre än den kärleksfulla förmaningen. Källmaterial som fotografier och arkitektur har också kommit att användas i de nya ansatserna. Dessa har i sin tur medfört att andra perspektiv på uppfostran och disciplinering har uppmärksammats. I en undersökning med fotografier som källmaterial har exempelvis sociologerna Eric Margolis och Sheila Fram visat en bredare palett av medel för disciplinering och övervakning än den fysiska bestraffningens. ${ }^{13}$

En annan huvudfåra i den barndoms- och utbildningshistoriska forskningen är att undersöka uppfostran och skola som verksamheter med föränderliga teknologier för disciplinering, bestraffningar och övervakning. Inriktningen har medfört synliggörande av alltfler förfinade teknologier för disciplinering, men samtidigt visat att äldre bestraffningsmetoder kvardröjt långt in på 1900-talet. Med hjälp av övergripande generaliserande kategorier (som bestraffning) har man bland annat kunnat visa att många av den "klassiska" bestraffningens utmärkande drag (riktad mot kroppen och offentligt utdelad) har dröjt kvar in i våra dagar. Trots att bestraffningstypen som sådan kritiserats i den offentliga diskursen. ${ }^{14}$ Andra studier har tagit fasta på övergången från fysiskt våld till symboliskt våld som allmänna utgångspunkter för att förstå disciplineringsteknikernas förändring. En sådan inriktning har bland annat lett till uppmärksammandet av en räcka tekniker för disciplinering som inte baseras på klassrumsnära handlingar av aktörer, och mottagare av dessa handlingar. Det kan röra sig om hur scheman, läsanvisningar, klassrumsindelningar, arkitektur, belöningar och uppmuntran samt kategoriseringar av elevgrupper verkade disciplinerande. Den här forskningen har alltså haft som avsikt att bredda och nyansera förståelsen av vad som kan utgöra korrektionsmedel i skolmiljö. ${ }^{15}$ Utan att vidare fördjupa mig i denna omfattande forskning så är min poäng att denna inriktning antingen har fäst stor vikt vid fysiska bestraffningar och dess övergång till symboliskt våld, eller uppmärksammat mer abstrakta former av disciplinering. Oavsett orientering så har en mer omfattande systematisering av olika disciplineringsformer (av fysisk eller symbolisk karaktär) under en längre sammanhängande tidsperiod inte gjorts.

I svensk forskning finns det ett par studier som särskilt behöver uppmärksammas. Historikern Tomas Berglund kan i sin avhandling, Det goda faderskapet i svenskt

12 Se exempelvis Rousmaniere, Dehli och de Coninck-Smith (1997), 275-76.

13 Eric Margolis och Sheila Fram, "Caught Napping: Images of Surveillance, Discipline and Punishment on the Body of the Schoolchild," History of Education 36, no. 2 (2007), 205-6.

14 Se exempelvis Herman et al. (2007), 208-12.

15 Några svenska exempel är Florin och Johansson (1997); Joakim Landahl, ”The Eye of Power(-lessness): On the Emergence of the Panoptical and Synoptical Classroom," History of Education 26, no. 6 (2013), 803-21; Björn Norlin, "School Jailhouse: Discipline, Space and the Materiality of School Morale in Early-Modern Sweden," History of Education 45, no. 3 (2016), 263-84. 
1800-tal, konstatera, utifrån en genomgång av ett stort antal rådgivningsskrifter om uppfostran från 1800-talet, att även mer hårdföra förespråkare av kroppsaga tycks med sitt agabegrepp ha laborerat med mildare agaformer i sin tillrättavisningsmanual. ${ }^{16}$ Berglund kan utifrån rådgivningslitteraturen urskilja fem olika former av aga i historisk tid: 1) kärleksfull förmaning; 2) allvarsam varning; 3) anmärkning, undandragande av förmån; 4) avskiljande från andra barn och deras nöjen och 5) aga med ris. ${ }^{17}$ En liknande iakttagelse har historikern Esbjörn Larsson gjort i en undersökning om växelundervisningens införande och verksamhet i Sverige under 1800-talets första hälft. Larsson menar att bestraffningsformerna i de anvisningar som gjordes av metodens grundare, Joseph Lancaster, knappt innehöll någonting om fysiskt våld. I stället fanns det en räcka andra metoder för att upprätthålla ordning, som dels var ordnade hierarkiskt och dels korresponderade mot olika sorters förseelser. Olika former av skamstraff och frihetsberövanden tycks ha tilltalat Lancaster. Också i de svenska handböcker, som anknöt till metoden, återfinns en liknande straffskala, men där nedflyttning, kvarsittning och förlöjliganden tycks ha varit mer förespråkade. ${ }^{18}$ Larsson antyder alltså att det fanns en systematik i hur straffen utformades, men han preciserar inte vad den "hierarkiska ordningen" eller den "formaliserade och finfördelade straffskalan" innehöll för typer av straff och hur de förhöll sig till varandra. Dessa forskningsresultat utgör delvis en kompareringsbar fond mot vilken mina modellgenererande undersökningar kan ställas.

\section{Undersökningens anspråk, relevans, avgränsningar och arkivmaterial}

Värdet av att arbeta fram en metod och modell för att analysera mönster och systematik över korrektionsformer är att den kan användas som verktyg för jämförelser mellan olika materialkategorier (exempelvis normativt material, diskursivt och material som beskriver hur människor handlat) och för att identifiera förändringar över tid samt att upptäcka geografiska variationer. Utöver dessa motiveringar kan det tilläggas att svenska folkskolereglementen i allmänhet är en underutnyttjad källa i utbildningshistorisk forskning, vilket på sina sätt är förvånande på grund av den betydelse dessa hade för att tolka och genomföra vad folkskolestadgan föreskrev samt förankra och anpassa denna efter rådande förhållanden i skoldistrikten. Den pluralism som kännetecknar 1800-talets skolväsende kommer till uttryck i detta material.

Den modell som jag i artikeln utvecklar baseras på påbjudna principer för korrigering av oönskade beteenden som fanns inom det allmänna skolväsendet under 1800-talet. Det finns flera orsaker till detta val. För det första finns det inga undersökningar som systematiserat har analyserat riktlinjer om tillrättavisningar och bestraffningar i den svenska folkskolan under 1800-talet. För det andra ger just detta material särskilt bra möjligheter för att systematisera hur lärare och skolråd påbjöds handla för att beivra förseelser i skolan, samtidigt som de också uttrycker vilka typer av förseelser som var oönskade.

Den här studien tar sin utgångspunkt i att mänskligt handlande, grovt sett, kan

16 Tomas Berglund, Det goda faderskapet i svenskt 1800-tal (Falun: Carlssons, 2007), 138-39.

17 Berglund (2007), 137. Se även Curtis (1997).

18 Esbjörn Larsson, En lycklig Mechanism: Olika aspekter av växelundervisningen som en del av 1800-talets utbildningsrevolution (Uppsala: Opuscula Historica Upsaliensia, 2014), 222-27. 
studeras på tre relaterade nivåer. Den första nivån handlar om riktlinjer och normer för handlande. Den regleras i lagstiftning, påbud eller regelverk för särskilda områden. Dessa sätter upp juridiska gränser för tillåtna, påbjudna handlingar och otillåtna. Den andra nivån kan kallas diskursiv och till den kan offentliga diskussioner om mänskligt handlande räknas. Diskursen innefattar riktlinjer i form av råd och principer för handlande, motiv för att handla på ett särskilt sätt eller berör konsekvenser av ett speciellt agerande. På den diskursiva nivån finns det utrymme för olika uppfattningar om den sak som diskuteras. Den tredje nivån handlar om praktiken, det vill säga hur människor faktiskt handlar och vilka reaktioner dessa handlingar får. Ett anspråk på en fullödig undersökning om förändringar av korrektionsmetoder i förfluten tid behöver behandla alla dessa tre nivåer och förstå hur nivåerna inverkar på varandra. Sådana anspråk görs inte i denna artikel, utan i stället utvecklar jag - utifrån den normativa nivån - en modell för att analysera föreskrifter om ordning och tukt. Förhoppningen är dock att denna i förlängningen ska erbjuda ett verktyg för att analysera materialtyper även på de andra nivåer som nämnts ovan. I den sammanfattande diskussionen kommer jag också att utveckla några resultat som modellen har bidragit till att identifiera och som förhoppningsvis kan utgöra utgångspunkter för vidare undersökningar på fler nivåer.

\section{Artikelns centrala begrepp}

I undersökningen och utvecklingen av modellen lanseras en begreppsapparat för att analysera textpassager om ordningens upprätthållande i folkskolereglementen. Innebörden av dessa begrepp presenteras efterhand, men några övergripande kommentarer om dessa är befogade. För det första talar jag om olika former av aga som delas upp i sekvensordning. Med sekvensordning förstås agaformernas påbjudna ordningsföljd och den delas i sin tur in i tre underkategorier: korrektionsformer, åtgärdsmoment och åtgärdsrum. Vad dessa begrepp innebär behandlas i undersökningen.

Eftersom ordet aga, ensamt eller som för-, eller efterledled i olika sammansatta ord, förekommer frekvent skall något sägas om detta begrepp. Aga betyder enligt Nationalencyklopedin "kroppslig bestraffning av minderåriga i uppfostrande syfte". ${ }^{19}$ Det torde också vara den vardagliga betydelsen av ordet idag. Ordet har emellertid haft en vidare betydelse före 1900-talet. I Svenska Akademiens ordbok exemplifieras betydelsen av ordet under tidigmodern tid och den visar att ordet aga kunde åsyfta att tukta, hålla ordning eller att hålla efter förhållanden utan en särskild bestämning av våldsinslag och inte enbart i uppfostrande syfte. ${ }^{20}$ Ordet aga kunde alltså syfta till en räcka av olika disciplinerande handlingar, bland annat i uppfostrande syfte, av mildare eller mer hårdhänta slag. Samma förhållande råder när det gäller ordet tukta som enligt Svenska Akademiens ordlista kan betyda bestraffa fysiskt eller forma. ${ }^{21}$ Under 1800-talet förefaller ordet tukt ha en vidare innebörd än fostran, medan aga och straff var medel som kunde användas för att fostra. ${ }^{22}$ Det innebär att man inte utan vidare kan använda den nutida betydelsen av ordet aga för att förstå agans his-

\footnotetext{
19 Nationalencyklopedin, uppslagsord "aga".

20 Svenska Akademiens ordbok (SAOB), uppslagsord "aga".

21 Svenska Akademiens ordlista (SAOL), upplaga 14, uppslagsord "tukta". I Nationalencyklopedin betyder tukta bestraffa.

22 Berglund (2007), 146-53 (särsk. 151).
} 
toriska innebörder. Den betydelse av ordet aga som det här är fråga om handlar naturligtvis om korrektionsmedel i uppfostrande syfte. För att inte sammanblanda den nutida betydelsen av ordet aga med dess historiska innebörder vill jag understryka att begreppen aga och korrektionsmedel här används som synonymer. Jag använder alltså mer den historiska innebörden av ordet aga än den nutida.

\section{Upprätthållande av ordning i skolstadgor och reglementen 1842-1900}

Folkskolereglementena var skoldistriktens viktigaste dokument för att implementera folkskolestadgan på lokal nivå. 1842 års stadga drog upp allmänna riktlinjer som motiverade folkskolans införande, fastslog finansieringsformer för den, förpliktigade församlingarna att anskaffa en skolbyggnad och att anställa en lärare. Den reglerade också hur läraren skulle anställas, vem som kunde anställas och hur skolan lokalt skulle styras genom en skolstyrelse. Stadgan innehöll naturligtvis också anvisningar om folkskolans läroämnen, dess antal och huvudsakliga innehåll. Många detaljfrågor som rörde skolans organisation, såsom skoldistriktets indelning i skolrotar (läslag), finansiering (hur skatt skulle uppbördas och fördelas) och läsordningar (exempelvis hur långa terminerna skulle vara) beslutades i varje distrikt för sig. Till dessa, från kunglig maj:t lokalt delegerade beslutsfrågor, hörde också vad som förväntades av läraren, hur denne och eleverna förväntades uppföra sig samt ordningsfrågor i klassrummen. Ingen av dessa för folkskoleväsendet viktiga frågor lade kunglig maj:t sig i (grovt sagt) mer än såtillvida att innehållet inte fick strida mot stadgan och att distriktens reglementen skulle passera domkapitlen innan godkännande. ${ }^{23}$

Efter 1842 reviderades folkskolestadgan två gånger fram till år 1900. De ovan beskrivna principerna för hur skolväsendet organiserades och hur bestämmande över olika frågor fördelades mellan lokala, regionala och centrala instanser förändrades inte under 1800-talet. Förvisso kom stadgorna från 1882 och 1897 att öka precisionsgraden i regleringen av skolväsendet på flera nivåer. Men formuleringarna om ordningsfrågorna förändrades inte, utan utformningen av dem de låg orörda kvar i skoldistriktens händer.

Reglementena var offentliga dokument i flera betydelser. Förslag till reglementen togs fram i skolstyrelsen (efter 1864 benämnt skolråd), vars medlemmar valdes av skoldistriktens röstberättigade församlingsbor. ${ }^{24}$ Därefter inhämtades församlingens synpunkter på sockenstämma (efter 1864 på kyrkostämma) som också godkände reglementet, varefter den skickades till domkapitlet för fastställande. ${ }^{25}$ Innehållet kommunicerades till församlingen från predikstolen och reglementet delgavs elevernas målsmän genom att exemplar hängdes upp i klassrummen.

23 Domkapitlen hade genom detta en (i kunglig maj:ts ställe) övervakande funktion på regional nivå. Folkskolestadga 1842, \$2; folkskolestadga 1882, kap. 2, \$10; folkskolestadga 1897, kap. 2, \$10.

24 Principerna för vilka i församlingen som hade rösträtt i dessa frågor har diskuterats av David Sjögren i "Folkskollärare i konflikt med skolråd och allmoge 1840-1900," i Nationen så in i Norden: En festskrift till Torkel Jansson, red. Henrik Edgren et al. (Skellefteå: Artos \& Norma Bokförlag, 2013), 183-97.

25 Exempelvis Reglemente för skolorna inom Blacksta skoldistrikt (Nyköping, 1890), 16; Reglemente för Folkskolor och Småskolor i Bromma församling (Ystad, 1889), 12; Reglemente för Brunnby skolor (utan tryckort, 1870), 7 och Reglemente för flyttbara folkskolorna i Bygdeå pastoratförsamling af Hernösands stift (Umeå, 1863), 7-8. 


\section{En analysmodell över korrektionsmedel i skolreglementen 1882-1900}

Stadgorna visar alltså att ordningsfrågorna var delegerade till skoldistriken och att det är i folkskolereglementena som information om åtgärder för ordningens upprätthållande kan inhämtas. Frågan är då hur man skall gå tillväga för att analysera innehållet i dessa. Skolväsendet var uppdelat i drygt 2500 skoldistrikt (vilket innebär lika många reglementen) och dessa ligger idag utspridda i landets kommunarkiv. Det har dock visat sig att en tämligen stor del av reglementena trycktes och lämnades som pliktexemplar till Kungliga biblioteket och universitetsbiblioteken. Där återfinns drygt 900 tryckta folkskolereglementen före år 1900 och dessa har fått utgöra materialet för undersökningen.

Undersökningen av dessa reglementen har givit några utläsbara mönster av mer generell natur. Ett sådant mönster är att reglementena inbördes blev allt mer lika varandra över tid. Den ökade standardiseringsgrad som kan skönjas särskilt efter 1882 innebär samtidigt att reglementena före (ungefär) 1882 uppvisade stora inbördes olikheter, vilket försvårar systematiseringsförsök av de föreskrivna korrektionsmedlen före 1880-talet. Ett annat mönster är att skoldistriktens reglementen reviderades, trycktes och gavs ut på nytt i samband med revisionerna av folkskolestadgan 1882 och 1897. Det innebär att över tid förändrades ordalydelserna om ordning i de olika distriktens reglementen. På grund av den relativa likhet reglementena sinsemellan hade efter stadgerevisionen 1882 är det lämpligt att först redovisa urskiljbara mönster i dessa reglementen för att sedan övergripande analysera disciplineringsmedlen före 1880-talet.

Genomgången av materialet från och med 1882 visar ett sammanhållet och tämligen omfattande tillrättavisnings- och bestraffningssystem som uppvisar relativt stor likformighet under 1880-talet och 1890-talet. Systemet baserades på idén att mildare och strängare korrektionsformer var tänkta att vidtagas i en särskild ordning. För att i detalj analysera dessa korrektionsformers inbördes förhållande har jag utarbetat en abstraktion utifrån en genomgång av alla tryckta reglementen under 1880-talet och 1890-talet. I grova drag uppvisar reglementena inbördes stora likheter, men i sina detaljer skiljer de sig åt från varandra. Abstraktionen är tänkt att identifiera både dessa övergripande likheter och finna sätt för att identifiera och analysera skillnader. Abstraktionen, som presenteras i tabell 1 och som diskuteras på följande sidor, är alltså mina systematiseringsförsök av reglementenas föreskrifter gällande de tillrättavisnings- och bestraffningsmedel som stod till buds för att se till att eleverna följde de uppförandenormer som reglementet ställde upp. 
Tabell 1. Abstraktion över korrektionsformer i folkskolereglementen 1882-1900

\begin{tabular}{|c|c|c|c|c|c|}
\hline \multicolumn{2}{|c|}{$\begin{array}{l}\text { Agaformer } i \\
\text { sekvensslag }\end{array}$} & $\begin{array}{l}\text { Konsekvens- } \\
\text { schema } 1\end{array}$ & $\begin{array}{l}\text { Konsekvens- } \\
\text { schema } 2 \\
\text { (Uppsala- } \\
\text { modellen) }\end{array}$ & $\begin{array}{l}\text { Konsekvens- } \\
\text { schema } 3 \\
\text { (Härnösands- } \\
\text { modellen) }\end{array}$ & $\begin{array}{l}\text { Konsekvens- } \\
\text { schema } 4 \\
\text { (Lunda- } \\
\text { modellen) }\end{array}$ \\
\hline \multicolumn{6}{|c|}{$\begin{array}{l}\text { Korrektionsform } \\
\text { tillrättavisning }\end{array}$} \\
\hline \multirow{2}{*}{$\begin{array}{l}\text { Första } \\
\text { ätgärds- } \\
\text { moment }\end{array}$} & & $\begin{array}{l}\text { Kärleksfullt } \\
\text { tilltal }\end{array}$ & Förmaning & $\begin{array}{l}\text { Kärleksfullt } \\
\text { tilltal }\end{array}$ & \\
\hline & I andra rum & $\begin{array}{l}\text { Allvarlig } \\
\text { varning }\end{array}$ & & $\begin{array}{l}\text { Allvarlig } \\
\text { varning }\end{array}$ & Varning \\
\hline \multicolumn{6}{|c|}{$\begin{array}{l}\text { Korrektionsform } \\
\text { bestraffning }\end{array}$} \\
\hline \multirow{4}{*}{$\begin{array}{l}\text { Andra } \\
\text { åtgärds- } \\
\text { moment }\end{array}$} & I tredje rum & $\begin{array}{l}\text { Anmärkning } \\
\text { i bok }\end{array}$ & $\begin{array}{l}\text { Nedflyttning } \\
\text { (i straffklass) }\end{array}$ & $\begin{array}{l}\text { Resa sig och bli } \\
\text { stående }\end{array}$ & $\begin{array}{l}\text { Felets } \\
\text { anteckning }\end{array}$ \\
\hline & I fjärde rum & & Avskild plats & $\begin{array}{l}\text { Anmärkning } \\
\text { i bok }\end{array}$ & Avskild plats \\
\hline & I femte rum & & $\begin{array}{l}\text { Anmärkning } \\
\text { i bok }\end{array}$ & $\begin{array}{l}\text { Framkallande } \\
\text { av ånger }\end{array}$ & Nedflyttning \\
\hline & I sjätte rum & & & & $\begin{array}{l}\text { Framkallande } \\
\text { av blygsel och } \\
\text { ånger }\end{array}$ \\
\hline $\begin{array}{l}\text { Tredje } \\
\text { åtgärds- } \\
\text { moment }\end{array}$ & $\begin{array}{l}\text { I näst sista } \\
\text { rum }\end{array}$ & $\begin{array}{l}\text { Lindrig/lämplig } \\
\text { kroppsaga }\end{array}$ & $\begin{array}{l}\text { Lämplig } \\
\text { kroppsaga }\end{array}$ & $\begin{array}{l}\text { Lämplig/lindrig } \\
\text { kroppsaga }\end{array}$ & $\begin{array}{l}\text { Lämplig } \\
\text { kroppsaga }\end{array}$ \\
\hline $\begin{array}{l}\text { Fjärde } \\
\text { åtgärds- } \\
\text { moment }\end{array}$ & I sista rum & $\begin{array}{l}\text { Annan åtgärd av } \\
\text { målsmän) }\end{array}$ & kolrådets 0 & de i samråd me & lärare (och \\
\hline
\end{tabular}

Abstraktionen skall förstås som en första generell systematisering av de tillrättavisnings- och bestraffningsåtgärder som behandlades i reglementena. Tabellens vänsterkolumn uppmärksammar tre sekvensslag i fallande ordning. Det första sekvensslaget kallas korrektionsform, det andra sekvensslaget kallas åtgärdsmoment och det tredje sekvensslaget åtgärdsrum. Jag skall nedan beskriva hur identifieringen av sekvensslagen i reglementena har gått till (begreppen återfinns ju inte i källtexterna), exemplifiera på vilket sätt reglementena gör skillnader på sekvensslagen och ingående beskriva sekvensslagen i sig. Jag skall också, när det är befogat, upplysa om reglementen som avviker från de generaliseringsanspråk som jag gör. Man bör komma ihåg att på detaljnivå är reglementena så pass olika varandra att inget påstående kan gälla dem alla; något undantag från ett generellt påstående kan nämligen alltid påträffas. Innan jag uppmärksammar sekvensslagen bör jag dock kort förklara vad som avses med konsekvensschema. Ett konsekvensschema är ett reglementes omnämnda åtgärdsformer och deras inbördes ordning. Det finns fyra sådana åtgärdsordningar som förekommer med större frekvens. Dessa övergripande konsekvensscheman kommer att diskuteras mer ingående nedan. 


\section{Agaformernas sekvensslag}

Enligt reglementena förväntades läraren använda en rad olika medel för att upprätthålla ordning. Generellt kan man konstatera att reglementena utgick från att läraren först rekommenderades använda olika former av mildare tillrättavisning, i allmänhet genom tilltal, varning eller förmaningar. När dessa tillrättavisningar prövats rekommenderas läraren sedan använda bestraffningar som korrektionsform. Skillnaden mellan tillrättavisnings- och bestraffningsformer görs många gånger tydliga i reglementena genom kursivering eller annan emfas. I folkskolereglementet för Björklinge skoldistrikt görs exempelvis klar boskillnad mellan korrektionsformerna:

Om barn utan giltigt skäl försummar skolan, och om det gör sig skyldigt till lättja,
olydnad, oordentlighet eller annat oskick, skall det först av läraren tillrättavisas, däref-
ter, om förmaningen ej hörsammas, straffas med nedflyttning, afskild plats, ogillande
vitsord i anmärkningsbok eller dylikt.
I fall af uppenbart trots eller fortsatt svårare förseelse må lärjunge äfven kunna af lä-
raren (lärarinnan) med lämplig kroppsaga tuktas [all kursivering och styckeindelning
i original]. ${ }^{26}$

Tillrättavisningen hade sina särskilda åtgärder och bestraffningen sina. Korrektionsformerna kunde enligt reglementena generellt inte blandas samman. Man kan också notera att tillrättavisningar tillgreps vid enstaka förseelser av slarv eller olydnad. Bestraffningar användes efter någon form av påminnelse av felet och vid upprepade förseelser. Inte alla reglementen gör en så tydlig åtskillnad mellan korrektionsformerna som Björklinge skoldistrikt. Dock återfinns distinktionen i olika former i flertalet reglementen. Reglementet i Ängelholms skoldistrikt är ett exempel där distinktionen återfinns, men framkommer inte lika tydligt som i Björklinges reglemente:

Om att [sic] barn gör sig skyldigt till någon förseelse af mindre svår beskaffenhet, skall det först tillrättavisas genom vänlig förmaning och varning; därefter, om sådan tillrättavisning icke hörsammas, må särskild plats i lärorummet, nedflyttning under medlärjungar, förseelsens anteckning eller annan dylik, till framkallande af ånger lämplig bestraffning användas. ${ }^{27}$

Åtgärderna för att beivra förseelser var även i Ängelholm å ena sidan tillrättavisningar och å andra sidan bestraffningar. Vissa reglementen använder dock inte ordvalen tillrättavisning och bestraffning för att markera olika korrektionsformer. Det gäller framför allt gruppen reglementen som tillhör konsekvensschema $1 \mathrm{i}$ tabell 1 och som jag skall återkomma till lägre fram. ${ }^{28}$ Så gott som samtliga markerar dock någon form av sekvensbestämning, exempelvis "förnyade förseelser", för att göra åtskillnad mellan de två korrektionsformerna, även om inte begreppen tillrättavisning och bestraffning används. ${ }^{29}$ Det kan också noteras att tillrättavisningarna ofta beskrev hur

26 Folkskolereglemente för Björklinge skoldistrikt (Uppsala, 1891), 18.

27 Reglemente för Engelholms stads folk- och småskolor (Stockholm, 1896), 10.

28 Exempelvis Reglemente för folkundervisning i Ervalla skoldistrikt (Nora, 1895), 10.

29 Exempelvis Reglemente för skolorna inom Brunskogs skoldistrikt (Karlstad, 1887), 10. 
korrektionsformen skulle användas, exempelvis "kärleksfullt", "vänligt" eller "allvarlig". ${ }^{30}$

Det andra och tredje sekvensslaget, som finns i tabellens vänsterkolumn, kallas åtgärdsmoment och åtgärdsrum. Ett åtgärdsmoment är en samlingsbeteckning för ett mer bestämt slag av tillrättavisnings- eller bestraffningsåtgärder som följde efter en särskild typ av förseelse. Flera slag av konkreta åtgärder kunde användas inom ett åtgärdsmoment och de hade i allmänhet likvärdig "stränghet" eller kunde användas som variation på likartade förseelser. Åtgärdsrum beskriver i första hand i vilken ordning specifika agaformer ordagrant omnämns i reglementena, men de är i andra hand också en tolkning av reglementenas avsikter ifråga om att konkreta agaformer var tänkta att användas i en förutbestämd ordningsföljd. De tre sekvensslagen används alltså sammantaget för att urskilja ordningsföljder på både generell och konkret nivå. Reglementet från Allerums skoldistrikt, som här får exemplifiera ungefär en fjärdedel av alla undersökta reglementen, tillhandahåller ett bra exempel för att konkretisera mina generella resonemang:

Om ett barn gör sig skyldig till olydnad, lättja eller annat oskick, skall det först tillrätta-
visas genom förmaning och varning; derefter, om sådan tillrättavisning ej hörsammas,
straffas genom felets anteckning, afskild plats, nedflyttning eller annan dylik, till fram-
kallande af blygsel och ånger tjenlig näpst. [nytt stycke i original]
Vid fortsatt och svårare förseelse må lärjunge med lämplig kroppsaga tuktas. [nytt
stycke i original]
Skulle ett barn icke låta sig rätta, utan genom fortsatt vanart och dåligt uppförande
utöfva ett skadligt inflytande på sina kamrater, eller begår det gröfre förbrytelser, skall
läraren eller lärarinnan sådant anmäla för skolrådets ordförande, som eger att i sam-
råd med lärare och skolråd vidtaga lämpliga åtgärder. ${ }^{31}$

I reglementet kan man först identifiera de två korrektionsformerna, nämligen tillrättavisningar och bestraffningar. Man kan också identifiera fyra åtgärdsmoment som i reglementet åtskiljs med orden "först", "derefter", "[v]id fortsatt" och "[s]kulle ett barn icke låta sig rätta [...]". Det tredje och färde åtgärdsmomentet åtskiljs från de övriga i texten dessutom av nya stycken. ${ }^{32}$ Slutligen kan man identifiera föreskrivna konkreta åtgärder i en ordning, nämligen ordningen förmaning, varning, felets anteckning, avskild plats, nedflyttning, framkallande av blygsel och ånger, kroppsaga och slutligen andra lämpliga åtgärder. Reglementet har alltså åtta åtgärdsrum.

Långt ifrån alla skoldistrikt har (i detta avseende) så tydligt uppdelade reglementen som Allerum hade. Vanligt var mer kompakt text, men där de fyra åtgärdsmoment ändå kan urskiljas. Ett sådant exempel är reglementet i Brunskogs skoldistrikt:

\footnotetext{
Begår ett skolbarn någon förseelse, skall lärare eller lärarinnan efter felets beskaffenhet tillrättavisa barnet genom kärleksfullt tilltal, allvarlig varning eller anmärkning i dagboken. Skulle något barn visa fortfarande gensträfvighet och trots, skall det nedflyttas i straffklass, hvarefter det vid förnyade förseelser kan blifva underkastadt lindrig kroppsaga af läraren i närvaro af skolrådsledamot eller tillsyningsman.
}

30 Exempelvis Reglemente för folkundervisningen inom Gällersta skoldistrikt (Örebro, 1899), 13.

31 Reglemente för Allerums sockens folk- och småskolor (Helsingborg, 1894), 5.

32 Reglementet i Allerum är för övrigt ett exempel på vad som i tabell 1 kallas konsekvensschema 4. 
Derest något barn icke låter sig rätta, utan genom vanart och dåligt uppförande utöfvar ett skadligt inflytande på de andra barnen, göre läraren anmälan derom till skolrådets ordförande, som i samråd med lärare och skolråd vidtager de åtgärder, hvilka af omständigheterna påkallas. ${ }^{33}$

Åtgärdsmomenten kan i Brunskogs reglemente urskiljas genom orden "fortfarande", "hvarefter" och "derest något barn icke låter sig rätta". Alla reglementen följer dock inte mönstret med fyra urskiljbara åtgärdsmoment. Ett exempel på en grupp reglementen där åtgärderna inte är preciserade i fyra moment är reglementet i Arnäs skoldistrikt:

a) Begår ett skolbarn någon förseelse, skall läraren eller lärarinnan efter felets beskaffenhet tillrättavisa barnets genom kärleksfullt tilltal, allvarlig varning, tillsägelse att resa sig upp från sin plats och under någon kortare stund bli förblifva stående, förseelsens anteckning i dagboken eller annan dylik af ånger lämplig bestraffning. Allt skymfande vare förbjudet.

b) Skulle något barn visa fortfarande gensträfvighet och trots, må det vid förnyad förseelse kunna blifva underkastadt lindrig och lämplig kroppsaga af läraren eller lärarinnan.

c) Därest något barn icke låter sig rätta utan genom vanart och dåligt uppförande utöfvar ett skadligt inflytande på de andra barnen, göre läraren eller lärarinnan anmälan därom till skolrådets ordförande, som i samråd med lärare och skolråd vidtage de åtgärder, hvilka af omständigheterna påkallas. ${ }^{34}$

I Arnäs reglemente åtskiljs abstraktionsmodellens första, tredje och fjärde åtgärdsmomentet genom både styckesindelning och bestämd ordningsföljd (markerat med a, b, c). Det kan uppmärksammas att skillnaden mellan tillrättavisningar och bestraffningar i Arnäs reglemente är otydligare än exemplen ur Björklinges och Allerums reglementen och att det första och andra åtgärdsmomentet i Arnäs reglemente därmed flyter samman. Ytterligare ett exempel på uppdelningar i åtgärdsmoment är reglementet i Boo skoldistrikt. Detta reglemente uppvisar dock flera avvikande drag i förhållande de allmänna mönstren:

Tillrättavisning och bestraffning vare:

a) i allmänhet anteckning af försummelse eller förfallolös frånvaro i skolans dagbok, för öfrigt

b) kärleksfullt tilltal, allvarlig varning eller afskild plats,

c) nedsatt sedebetyg.

d) Därest ett barn visar fortfarande gensträfvighet, trots eller olydnad må det af läraren eller lärarinnan kunna blifva underkastadt lämplig kroppsaga.

e) Därest lärjunge hvarken genom varningar eller bestraffningar låter sig rättas, utan genom vanart och dåligt uppförande utöfvar ett skadligt inflytande på sina kamrater, göre läraren eller lärarinnan anmälan derom $[\ldots] .^{35}$

Trots att reglementet i Boo skoldistrikt har en femgraderad uppräkning så kan det

33 Reglemente för skolorna inom Brunskogs skoldistrikt (Karlstad, 1887), 10.

34 Reglemente för skolorna inom Arnäs skoldistrikt i Wester-Norrlands län (Örnsköldsvik, 1899), 10.

35 Reglemente för skolorna inom Boo församling (Stockholm, 1886), 25-26. 
urskiljas fyra åtgärdsmoment som åtskiljs genom "för öfrigt", punkt (efter sedebetyg), "fortfarande" (under d) och "[d]ärest lärjunge hvarken genom varningar och bestraffningar låter sig rättas" (under e). Det kan också noteras att skiljelinjen mellan korrektionsformerna tillrättavisning och bestraffning är svår att finna i detta reglemente.

Åtgärdsmomenten är alltså inte alltid lika tydligt separerade som i reglementet från Allerum, men markeras generellt genom styckeindelning, kursivering, styckeindelning, tids- eller sättsadverbial (exempelvis "först", "derefter" eller "fortsatt"36, "fortfarande" ${ }^{37}$ ) och fraser som "[1]åter det sig häraf icke rätta [...]"38, "[...] vid förnyad förseelse [...]"39, "[s]kulle något af dessa bestraffningssätt ej göra tillfyllest [...]"40 eller "[d]erest något barn deraf ej låter rätta [...]"41. Det allmänna mönstret är alltså att åtgärdsmomenten separeras i en sorts sekvensskala. Det betyder att först skall en åtgärd prövas och, om detta inte hjälper, stegras åtgärderna successivt - och enligt en särskild ordning. Det bör dock noteras att inte alla undersökta reglementen gör åtskillnad mellan det första och det andra åtgärdsmomentet, utan en grupp reglementen räknar upp en rad åtgärder som kunde användas efter "felets beskaffenhet". ${ }^{42}$ Enligt dessa reglementen var läraren mer obunden ifråga om åtgärdsform i första och andra åtgärdsmomentet. Därefter gjordes en åtskillnad, med samma typ av ordval som exemplifierats ovan, vid det tredje åtgärdsmomentet. ${ }^{43}$ Reglementen som tillhör konsekvensschema ett och tre hade i regel den mer obundna ordalydelsen, medan de reglementen som tillhörde konsekvensschema två och fyra hade en striktare sekvensindelning. Antalet reglementen som tillhör respektive konsekvensschema presenteras i figur 1 nedan.

Det fanns dock reglementen som frångår det allmänna mönstret om att kroppsbestraffningar alltid skulle föregås av mildare former av tillrättavisningar. Reglementet i Baltacks skoldistrikt är ett sådant exempel.

Kroppsaga må ej användas, utan att varning eller anmärkning i dagboken har föregått. Om lärare så pröfvar nödigt, må dock kroppslig aga användas, äfven då svårare förseelse första gången iakttages; men må i sådant fall förhållandet utan dröjsmål anmälas hos skolrådets ordförande. ${ }^{44}$

Texten förespråkade alltså användandet av mildare tillrättavisningsformer före kroppsaga som generell princip, men vid särskilda omständigheter kunde den regeln kringgås. Sekvensordningen kunde alltså sättas ur spel om läraren ansåg det befogat.

36 Exempelvis Reglementen för folkskolor och småskolor i Augerums församling af Lunds stift (Karlskrona, 1885), 10.

37 Exempelvis Reglemente för skolorna i Dalby skoldistrikt (Karlstad, 1882), 14.

38 Exempelvis Reglemente för Björkviks församlings skolors (Nyköping, 1882), 5-6.

39 Exempelvis Reglemente för Björkviks skoldistrikt (Nyköping, 1895), 10.

40 Exempelvis Reglemente för Efveröds församlings skolor (Lund, 1877), 6.

41 Exempelvis Förslag till reglemente för Engelholms församlings folkskolor (Lund, 1876), 8.

42 Exempelvis Reglemente för skolorna inom Gåxsjö skolistrikt (Östersund, 1899), 11; Reglemente för folkundervisningen inom Almby skoldistrikt (Örebro 1887), 10 och Reglemente för Alsens skoldistrikt (Östersund, 1898), 10.

43 Exempelvis Reglemente för folkundervisning i Ervalla skoldistrikt (Nora, 1895), 10.

44 Reglemente för folkundervisningen inom Baltacks skoldistrikt (Skara, 1899), 9. 
Reglementet villkorade dock lärarnas möjligheter att gå förbi mildare tillrättavisningsåtgärder genom en sorts anmälningsplikt och det kan i sin tur möjligen tolkas som en avsikt att kringskära lärarnas strängare bestraffningsbefogenheter.

Åtgärdsmomenten har utarbetats som analysbegrepp för att i ett stort antal reglementen identifiera och beskriva korrektionsåtgärdernas inbördes ordning i allmänhet. Åtgärdsrum är ett annat analysbegrepp som används för att synliggöra och analysera andra saker. För det första vill jag belysa antalet tillrättavisnings- och bestraffningsåtgärder som fanns inom ett skoldistrikt genom att placera dem i rum enligt den ordning som de omnämns i reglementena. För det andra vill jag därmed sammanföra ordagrant lika reglementen i grupper, vilket jag återkommer till nedan. För det tredje vill jag med hjälp av den ordagranna överensstämmelsen styrka min tolkning att åtgärdsmomentens ordningsföljd var avsiktligt framskriven och att ordvalen var genomtänkta. För det fjärde vill jag också upptäcka avvikande tillrättavisnings- och bestraffningsåtgärder och diskutera hur man skall förstå dem.

Placeras tillrättavisnings- och bestraffningsformerna i åtgärdsrum efter den ordning som de omnämns i reglementena så uppenbaras några övergripande mönster. Den första tillrättavisningsåtgärden var med väldigt få undantag antingen kärleksfullt tilltal eller förmaning. ${ }^{45}$ I andra åtgärdsrum föreskrevs med få undantag varning. ${ }^{46}$ I näst sista åtgärdsrum föreskrevs med mycket få undantag kroppsaga, antingen med bestämningen "lindrig" eller "lämplig". ${ }^{47}$ Några få reglementen omnämnde överhuvudtaget ingen kroppsaga. ${ }^{48} \mathrm{I}$ dessa fanns alltså heller inget tredje åtgärdsmoment. I sista åtgärdsrum föreskrevs - med ett påträffat undantag - att läraren skulle anmäla förseelserna till skolrådets ordförande. ${ }^{49}$ Denne hade, enligt reglementena, sedan i uppgift att antingen a) enskilt, eller b) efter samråd med skolrådet och/eller c) i samråd med läraren besluta om ytterligare åtgärder. Några få reglementen föreskrev att underrättelsen också skulle nå målsmän och att samråd om åtgärder skulle ske med dem. ${ }^{50}$

Reglementena uppvisar alltså påfallande likheter avseende vilka åtgärdsformer som placeras i de två första åtgärdsrummen och i de två sista. I kontrast till detta mönster uppvisar reglementena en påfallande olikhet när det gäller vilka åtgärder som omnämns i tredje till och med sjätte åtgärdsrummet. Det finns ett antal vanligt

45 Jag har hittat tre undantag bland tryckta reglementen 1882-1900, nämligen Everöd (varning), Boo (anteckning i bok) och Askersund (rätta de felande).

46 En grupp av reglementen, den som kallas konsekvensschema $2 \mathrm{i}$ tabell 1 , påtalade enbart en åtgärd i första åtgärdsmomentet. De omnämner nedflyttning som den andra åtgärden i ordningen. I mina konsekvensscheman lämnas dock det andra åtgärdsrummet tomt i konsekvensschema 2. Andra exempel på avvikelser från mönstret att varning kom i andra åtgärdsrum är Boo skoldistrikt (kärleksfullt tilltal) och Fors skoldistrikt (resa sig och förbli stående). Reglemente för skolorna inom Boo församling (Stockholm, 1886), 25-26.

47 Det finns mycket få andra ordval för bestraffningen än just lämplig eller lindrig kroppsaga. Glafva (måttlig), Björnekulla (tjenlig), Frödinge (tjenlig och behövlig) och Bodarne (handgripligen tillrättavisas) är de enda exemplen jag funnit.

48 Exempelvis Ervalla och Gråmantorp

49 Undantaget gäller Reglemente för såväl folkskola som småskola inom Degeberga skoldistrikt, Lunds stift (Kristianstad, 1891), 4. I några större stadsförsamlingar skulle läraren/lärarinnan anmäla till överläraren, men det kan knappast ses som ett undantag från regeln att anmäla till en högre tjänstefunktion, som ju skolrådets ordförande var på landsbygden där överlärare i regel saknades.

50 Exempelvis Reglemente för folkundervissningen i Gällersta skoldistrikt (Örebro, 1899), 13. 
förekommande åtgärdsformer som presenteras i tabell 1. Ordningen skiljer sig dock åt mellan olika grupper av reglementen.

\section{Fyra konsekvensscheman och deras inbördes skillnader}

Skillnaderna mellan reglementena gör att de kan grupperas i fyra konsekvensscheman som förekommer med större frekvens. Skillnaderna mellan dessa konsekvensscheman kan tyckas vara små, det är framför allt åtgärdernas ordning, enstaka ordval och antalet bestraffningsformer som skiljer dem åt. Det första konsekvensschemat laborerade enbart med fem åtgärdsformer, nämligen kärleksfullt tilltal, allvarlig varning, anmärkning i bok, lindrig eller lämplig kroppsaga samt annan åtgärd. Detta schema har till skillnad från de övriga ingen särskild geografisk anknytning, utan exempel på reglementen med detta schema återfinns i hela landet. ${ }^{51}$ Det andra schemat laborerade med sex åtgärdsformer, nämligen förmaning, nedflyttning (med tillägget "i straffklass" på några ställen), avskild plats, anmärkning i bok, lämplig kroppsaga och annan åtgärd. Reglementen identiska med denna ordning återfinns företrädelsevis i Uppsala stift och i stiften i Mälardalen. ${ }^{52}$ Det tredje schemat föreskrev sju åtgärdsformer, nämligen kärleksfullt tilltal, allvarlig varning, resa sig och förbli (för en stund) stående, anmärkning i bok, framkallande av ånger, lindrig eller lämplig kroppsaga och annan åtgärd. Sådana reglementen återfinns företrädelsevis i Härnösands stift. ${ }^{53}$ Man kan notera att i några av dessa reglementen från Härnösands stift återfinns tillägget "allt skymfande vare förbjudet".54 Detta är alltså en reglering av lärarens möjligheter att bestraffa eleverna. Det färde konsekvensschemat laborerade med åtta åtgärdsformer, nämligen förmaning, varning, felets anteckning, avskild plats, nedflyttning, framkallande av blygsel och ånger, lämplig kroppsaga och annan åtgärd. Detta schema användes framför allt av skoldistrikten i Lunds stift. ${ }^{55} \mathrm{Av}$ dessa scheman är det den färde, Lundamodellen, som uppvisar en stor kontinuitet över tid och inom stiftet. Med andra ord är avvikelser från schemat sällsynta i stiftets församlingar.

De skillnader schemana uppvisar, när det gäller åtgärdsformernas antal och ordning samt det första och tredje schemats sammansmältning av första och andra åtgärdsmoment, skall inte övertolkas. De betyder säkert inte att det fanns stora skillnader över landet i hur man betraktade folkskolans korrektionsformer, att man, så att säga, hade en annan uppfattning om bestraffningar i Karlstadstrakten än vad man hade i Skåne. Däremot tycks det ha utvecklats olika sätt att uttrycka och reglera korrektionsformer på, och som efterhand stelnade i scheman som sinsemellan skilde sig något åt. ${ }^{56}$ Likheten i hur korrektionsformerna uttrycktes inom samma stift tyder

51 Exempelvis Reglemente för skolorna i Alnö distrikt (Sundsvall, 1891), 11-12; Reglemente för skolorna $i$ Askers skoldistrikt (Örebro, 1887), 8; Reglemente för skolorna inom Borgviks församling (Karlstad, 1881), 10 och Reglemente för skolorna inom Frödinge skoldistrikt (Oskarshamn, 1894), 12-13.

52 Exempelvis Estuna skoldistrikt (Norrtälje, 1888), 10-11.

53 Exempelvis Reglemente för skolorna inom Arjepluogs skoldistrikt (Stockholm, 1899), 16.

54 Exempelvis Reglemente för skolorna inom Arnäs skoldistrikt $i$ Wester-Norrlands län (Örnsköldsvik, 1899), 10.

55 Exempelvis Förslag till reglemente för Barkåkra och Rebbelberga församlings skolor (Ängelholm, 1890), 11.

56 Det är också tänkbart att olikheterna avspeglar olika förhållningssätt till tillrättavisningar och bestraffningar som lärdes ut vid lärarseminarierna i landet. 
på att det antingen cirkulerade förslag, en förlaga till reglementen inom stiften, en förlaga som domkapitlen hade utarbetat, och som församlingarna sneglade på när de tog fram sina reglementen; eller att domkapitlen redigerade förslagen hårt innan godkännande. Det förstnämnda förfarandet är troligare eftersom en från domkapitlens sida hårdhänt redigering av reglementena skulle ha framtvingat (eller väckt krav på) nytt godkännande av reglementet i församlingarnas beslutande organ. ${ }^{57}$

Uppmärksammar man först schemanas inbördes likheter kan det konstateras att anmärkning, eller anteckning i journal eller dagbok förekommer i samtliga scheman, dock varierar rumsplaceringen. Varje skola skulle enligt folkskolestadgan ha en journal eller dagbok där anteckningar rörande eleverna fördes. ${ }^{58}$ Bestraffningen handlade alltså om att förseelsen antecknades i journalen. Anmärkningsboken hade i sin tur förlagor i liknande journalsystem som fanns vid elementarläroverken i början av 1830-talet. ${ }^{59}$ Varning är en åtgärd som påtalades i andra rum i tre av schemana. Det kan också noteras att varning alltid föregås av annan mildare åtgärd. Nedflyttning är en bestraffningsform som förekommer i två konsekvensscheman. Den bestraffningsformen förekommer utan eller med precisering. Nedflyttning är i sig ett svårtolkat begrepp. Troligen innebar det sällan nedflyttning i lägre åldersklass. 1842 års folkskola var inte uppdelad i klasser, och utvecklingen mot sådana tillkom senare etappvis. ${ }^{60}$ Första steget mot åldersindelade klasser togs $1858 \mathrm{i}$ och med att folkskolan delades i avdelningarna småskola och den egentliga folkskolan. Uppdelningen förtydligades sedan i 1882 års folkskolestadga och normalplanerna 1878,1889 och $1900 .{ }^{61}$ Därutöver förekom under hela denna period - och även flera decennier in på 1900-talet - skolformer där undervisning skedde avdelningsöverskridande. ${ }^{62}$ Nedflyttning torde alltså knappast ha inneburit fysisk klassförflyttning, eftersom klassindelning inte var en allmänt spridd företeelse under tidsperioden. Troligen handlade det om förändringar av elevens placering i undervisningsrummet, vilken var ordnad efter kön, kunskaper och moraliska förebilder. Preciseringen nedflyttning i straffklass, som förekommer i schema två, innebar att eleven urskildes från övriga för att efter förnyade förseelser riskera kroppsaga. Nedflyttningen inne-

57 Jag har i ett fall kunnat se att domkapitlet ändrade ett förslag till reglemente. Ändringen handlade om att domkapitlet i Göteborg tog bort "nedflyttning under medlärjungar" som åtgärdsform. Min undersökning tillåter dock inte att göra några jämförelser mellan skoldistrikten förslag och de reglementen som domkapitlen fastställde eftersom förslagen sällan tryckets om de inte godkänts av domkapitlen. Reglemente för Göteborgs stads folkskolor (Göteborg, 1899), 15 och Förslag till reglemente för Göteborgs stads folkskolor (Göteborg, 1898), 14.

58 Folkskolestadgan $1882 \S 44$, mom. 1; Folkskolestadgan $1897 \S 29$, mom. 5; 44, mom. 2.

59 Larsson (2014), 234.

60 År 1847 gick 46 procent av alla barn i den fasta folkskolan i växelundervisningsskolor. Denna skolform saknade klassindelningar efter ålder. Metodens principer överfördes delvis i folkskolan, vilket innebar att principen om den åldersintegrerade "klassen" levde kvar. Larsson (2014), s. 35-39, $107-12$.

61 Monika Vinterek, Åldersblandning i skolan: Elevers erfarenheter (Umeå: Umeå universitet, 2001), 20-25.

62 Margareta Mellberg, Pedagogen och det skrivna ordet: Skrivkonst och folkskollärare 1870-1920 (Göteborg: Göteborgs universitet, 1996), 36-40. 
bar inte någon fysisk åtskillnad till ett eget rum. ${ }^{63}$ Förfaringssättet hade åtminstone 40 år äldre förlagor i elementarläroverken. ${ }^{64}$

Schema två och fyra påtalade i fjärde åtgärdsrum bestraffningsformen "avskild plats", vilket rimligen avsåg fysisk åtskillnad av barn från deras plats bland den övriga elevgruppen. ${ }^{65}$ Materialet tillåter tyvärr inte vidlyftigare tolkningar. Schema tre och fyra har som bestraffningsform, i femte respektive sjätte åtgärdsrum, "framkallande av ånger" (i schema fyra med tillägget framkallande av "blygsel"). I båda schemana handlar det om en bestraffningsform som närmast föregick kroppsaga. Vad bestraffningen konkret innebar ger reglementena ingen information om, men det kan antas att det handlade om andra former av ångestframkallande straff än de som omnämndes i åtgärdsrummen dessföre. Dessa åtgärdsrum handlade i både schema tre och fyra om antingen anteckningar om förseelser eller om att urskilja eleverna från den övriga elevgruppen, antingen genom att avskilja dem, låta dem resa på sig eller flytta om dem i klassrummets hierarki (nedflyttning). De senare bestraffningsformerna är i sig mildare former av skamstraff och därför kan man anta att framkallande av ångestladdade olustkänslor betraktades som en mer kännbar bestraffning än mildare skamstraff.

\section{Andra scheman}

De ordagranna likheterna mellan utformning av de enskilda skoldistriktens reglementen och reglementena inom samma stift skall dock inte överdrivas. Många reglementen avviker från det schema som generellt kan utkristalliseras inom stiften ifråga. ${ }^{66}$ Avvikelserna gör också att det bildas en tämligen stor grupp reglementen som inte kan återföras till något av de omnämnda schemana. Denna grupp övriga reglementen uppvisar, i sin tur, i varierande grad avvikelser från de fyra schemana. Undantag från de fyra konsekvensschemana är alltså relativt vanliga, men det är knepigt att utifrån reglementena skapa ytterligare scheman med nämnvärt antal. Nog kan man hitta en handfull reglementen som skulle kunna bilda ytterligare en schematyp, men det skulle inte öka förståelsen av reglementenas inbördes olikheter avseende tillrättavisnings- och bestraffningsformer. Därför är det bättre att sammanföra alla undantag i förhållande till mina konsekvensscheman till en egen kategori

63 Jämför med ett utdrag ur en anmärkningsbok från läroverket: "Gör någon lärljunge sig känd för fortfarande lättja eller ett vanartigt uppförande, så att för honom kroppslig aga vader nödig, förklaras han vara i belägenhet att för hvarje förnyad förseelse kunna få stryk. Detta kallas att nedflyttas i stryk-klassen, hvarmed dock lika litet, som med skolans öfriga klasser förstås något särskilt rum.” Anmärkningsbok år 1859 för Carl Fr. Erdmann uti 1 klassen af nya elementarskolan i Stockholm, Stockholmskällan: https://stockholmskallan.stockholm.se/post/28106.

64 Florin och Johansson (1997), 43-72 (särsk. s. 50); Larsson (2014), 232-33. Florin och Johansson menar att nedflyttning i straffklass bara förekom på läroverken och inte i folkskolan. Förlagan till det som senare blev "kunskapsordningen" introducerades redan i 1649 års skolordning. Vid den lärda skolan gick den i princip ut på att man använde bänkraderna för att differentiera elevgruppen vad gällde deras inbördes kunskaper, men samtidigt kunde användas för att synliggöra moraliska förebilder och avskräckande moraliska exempel.

65 Åtgärden i tredje schemats, tredje åtgärdsrum att "resa sig och förbli stående" kan tolkas som en form av åtskillnad likvärdig att placeras på "avskild plats".

66 Exempelvis Reglemente för skolorna inom Arvidsjaurs lappmarks skoldistrikt (Härnösand, 1886), 9; Reglemente för skolorna inom Borgviks församling (Karlstad, 1881), 10 och Reglemente för såväl folkskola som småskola inom Degeberga skoldistrikt, Lunds stift (Kristianstad, 1891), 4 
och belysa skillnaderna med hjälp av exempel. Antalet reglementen som hör till respektive konsekvensschema presenteras nedan i figur 1 .

Figur 1. Frekvens av reglementen enligt olika grundscheman $(N=870)$

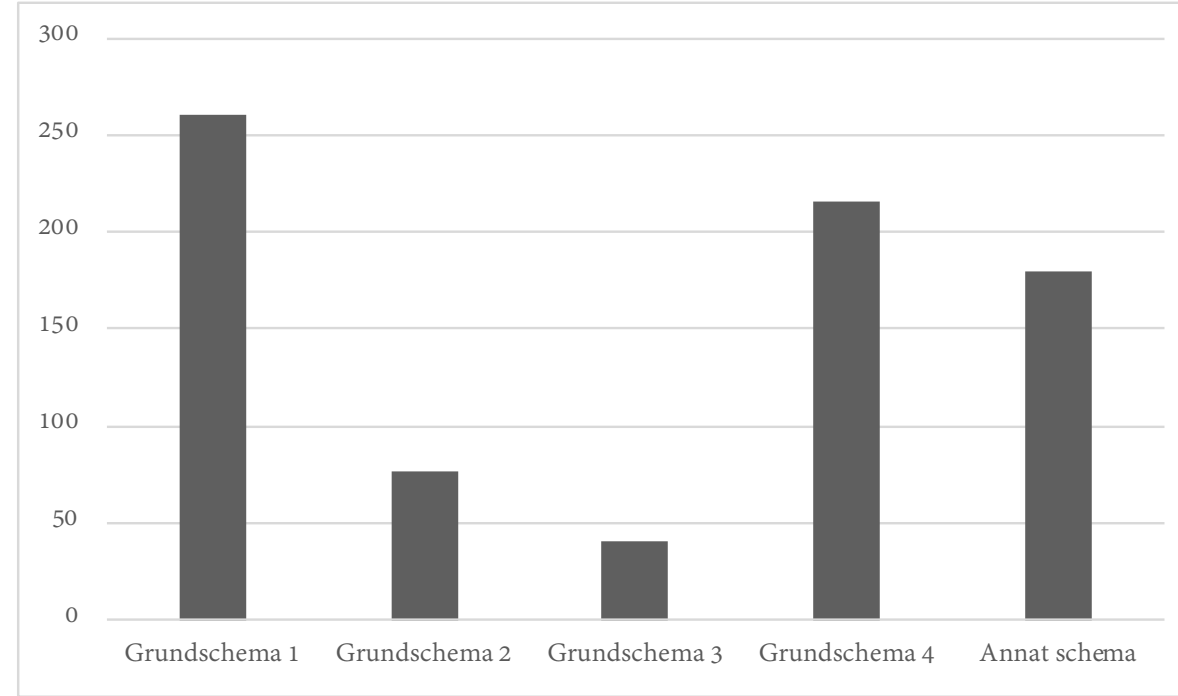

De scheman som avviker från de fyra konsekvensschemana bör i sin tur åtskiljas i två kategorier. Med första kategorin menas reglementen som innehåller samma tillrättavisnings- och bestraffningsformer som något av de fyra konsekvensschemana, men har färre bestraffningsformer och/eller en annan ordning. Av de sammanlagt 180 reglementen som tillhör ett annat schema är det drygt 100 stycken av denna kategori. Det rör sig alltså om små avvikelser från något av de fyra konsekvensschemana. Avvikelserna i den här kategorin handlar uteslutande om skillnader i andra åtgärdsmomentet. När det gäller avvikelser i andra åtgärdsmomentet kan dessa belysas genom några exempel: I Björksviks skoldistrikt inom Linköpings stift omnämndes först kärleksfull tillrättavisning, därefter nedflyttning, sedan skiljande från kamraterna samt sist lindrig och lämplig kroppsaga. ${ }^{67}$ Det är avsaknad av bestraffningsformen anmärkning i bok och preciseringen av avskiljandets natur som skiljer Björkviks reglemente från schema två. En annan form av mindre avvikelse återfinns i Glafva skoldistrikt i Karlstads stift. Där påtalades först kärleksfull tillrättavisning, därefter allvarlig varning, sedan anmärkning i bok samt sist måttlig kroppsaga. ${ }^{68}$ Det är alltså blott bestämningen av kroppsagans natur (måttlig i stället för lindrig/lämplig) som skiljer Glafva reglemente från schema ett. Ett tredje exempel är Gällersta skoldistrikt i Strängnäs stift. Ordningen bland korrektionsformerna i Gällersta var kärleksfullt tilltal, allvarlig varning, avskild plats, nedflyttning, anmärkning i bok och lämplig kroppsaga. Distriktet bytte alltså plats på tredje och fjärde åtgärdsrum-

67 Reglemente för Björkviks församlings skolor (Nyköping, 1895), 10-11. Se även Reglemente för skolorna inom Bladåkers skoldistrikt (Uppsala, 1890), 12.

68 Glafva skoldistrikt (Arvika, 1887), 10. I Frödinge skoldistrikt återfinns en liknande mindre avvikelse. Reglementet föreskriver där "tjenlig och behöflig kroppsaga". Reglemente för skolorna inom Frödinge skoldistrikt (Oskarshamn, 1894), 13. 
met i förhållande till konsekvensschema två. ${ }^{69}$ Ytterligare fem distrikt gjorde detta platsbyte (Almby, Edeby, Ängelholm, Gävle och Göteborg).

Med den andra kategorin avvikelse menas reglementen som skiljer sig ifrån de fyra konsekvensschemana på grund av att de omnämner andra bestraffningsformer. Det rör sig om drygt 50 sådana reglementen sammantaget och sju olika bestraffningsformer (kvarsittning, rätta de felande, förlust av ledighet, avskiljande från kamraterna, nedsatt sedebetyg och utvisning från klassrummet). Samtliga bestraffningsformer omnämndes $i$ andra åtgärdsmomentet. Det intressanta med dessa bestraffningsformer är att flera av dem behandlas ingående i växelundervisningsmetodens rådgivning om bestraffningar i skolan i början av 1800-talet. Ett sådant exempel är en bestraffningsform som påtalas i Esphults skoldistrikt. Reglementet i Esphult bytte ut tredje rummets bestraffningsform i schema fyra från "felets anteckning" till "anteckning å befintlig svart tafla af barnets skolnummer". ${ }^{70}$ Noteringen av begånget fel var alltså offentlig för alla elevers beskådan. Esbjörn Larsson påpekar att likande bestraffningar var ett signum i bestraffningsanvisningar i växelundervisningsskolor. Larsson tolkar metoden som ett uttryck för avsikten att synliggöra sambandet mellan förseelse och straff. ${ }^{71}$ Vidare menar Larsson att exempelvis Joseph Lancaster skall ha förespråkat frihetsberövande straff. I det sena 1800-talet folkskolereglementen förekommer de, i och för sig i mildare form än vad Lancaster själv förespråkade, i form av kvarsittning efter skoltidens slut. ${ }^{72}$ Andra former av frihetsberövande återfinns i Everöds och Björkviks reglementen där bestraffningen "förlust av ledighet under fristunderna" omnämndes i andra åtgärdsmomentet. ${ }^{73}$ Den senare formen av bestraffning var dubbel i sin natur eftersom den både var frihetsberövande och skiljde den felande eleven från kamraterna. Bestraffningsformen "afskiljande från kamraterna", som omnämns i Björkviks, Brämhults, Boo, Fogdö och Fors skoldistrikt, kan naturligtvis också ses som ett straff som skiljde ut en elev från gruppen. ${ }^{74}$ Bestraffningsformen utvisning från klassrummet påträffas i fem reglementen, ${ }^{75}$ Eksjö, Eskilstuna, Falsterbo, Fors och Gävle, och den skiljer sig på flera punkter från de övriga bestraffningsformerna. Utvisning är ett slags avskiljande straff, fast okontrollerad och utan övervakning från den som utdelade bestraffningen. I stället kan man tänka sig att den drabbade skulle komma till ångerinsikter under enskild kontemplation och att straffet möjliggör frirum för sådan aktivitet.

\section{Anvisningar om begränsning av kroppsstraff samt relationer mellan förseel- sens art och bestraffningens natur}

Min sammantagna tolkning av reglementenas föreskrifter om tillrättavisningar och bestraffningar är att kroppsbestraffning villkorades genom att påtala användandet av mildare korrektionsformer först. Systematiseringen av reglementenas föreskrifter

69 Reglemente för Folkundervisningen inom Gällersta skoldistrikt (Örebro, 1893), 10.

70 Reglemente för Esphults och Linneröds församlingars folkskolor (Kristianstad, 1886), 9-10.

71 Larsson (2014), 225.

72 Exempelvis Folkskolereglemente för Gäfle stads församlings skoldistrikt (Uppsala, 1884), 16. Jämför Larsson (2014), 223-27.

73 Reglemente för Efveröds församlings skolor (Lund, 1892), 4.

74 Reglemente för Björkviks församlings skolor (Nyköping, 1882), 5-6; Reglemente för folkundervisningen inom Brämhults skoldistrikt (Borås, 1883), 5.

75 Exempelvis Reglemente för Eskilstuna stadsförsamlings skolor (Eskilstuna, 1886), 4. 
visar att även om det finns skillnader mellan skoldistriktens bestraffningsformer så framträder ett tydligt mönster av först lättare tillrättavisningar och sedan av hårdare bestraffningar. Kroppsagan var i regel slutpunkten i en räcka av bestraffningsmedel som läraren själv kunde använda utan att blanda in andra parter. I flertalet reglementen synliggörs detta genom sekvenseringar som behandlats ovan.

Utöver sådana allmänna begränsningar i att använda kroppsbestraffning har det påträffats specifika förbehåll för kroppsaga. Några reglementen föreskrev exempelvis explicit att "[k]roppsaga må ej användas, utan att varning eller anmärkning i dagboken har föregått" ${ }^{76}$ Andra reglementen begränsade till och med lärarens användning av kroppsaga som bestraffningsmedel. I föreskrifterna i Brunskogs reglemente hette det att en elev "kan blifva underkastadt lindrig kroppsaga af läraren i närvaro af skolrådsledamot eller tillsyningsman" 77 och i Farstorp skoldistrikt menade man att kroppsaga skulle ske "i närvaro af dess föräldrar eller af en skolrådsledamot" ${ }^{78}$ I Gävle skoldistrikt kunde principen om att först pröva mildare tillrättavisningsformer innan kroppsaga sättas ur spel, om läraren fann det nödvändigt. Men gjordes sådant frånsteg skulle saken "oförtöfvat anmälas hos skolrådets ordförande [...]. ${ }^{79}$ Inom Göteborgs skoldistrikt föreskrevs att timlärare, slöjdlärare och handarbetslärarinnor inte fick använda kroppsbestraffning, utan de var tvungna att anmäla förseelserna till elevernas klasslärare eller klasslärarinna. ${ }^{80}$ Slutligen har ett reglemente påträffats vari kroppsaga inte omnämndes bland föreskrivna bestraffningsmedel..$^{81}$

Jag skall ge ytterligare ett exempel på ordalydelsen i ett reglemente för att åskådliggöra hur förbehållen för att använda kroppsaga uttrycktes. Samtidigt vill jag med detta exempel åskådliggöra relationerna mellan förseelsernas art och korrektionsmedel. Exemplet är hämtat från Degeberga skoldistrikts reglemente och däri uttrycktes förbehållen och relationerna mellan förseelseslag och påföljd på följande sätt:

\footnotetext{
Barn, som inom skolan begått smärre förseelser, som brister i uppmärksamhet, flit och ordning förmanas af lärare, och må nedflyttas för kortare tid under sina kamrater. Barn, som oaflåtigt visar liknöjdhet vid undervisningen, eller ofta gör sig skyldig till försumlighet, oordentlighet eller uppstudsighet, varnas ytterligare af läraren, straffas med längre tids nedflyttning och förehålles af skolrådets ordförande att visa förbättring. Skulle det oaktadt den önskade förbättringen icke visa sig, straffes den felande lärjungen af läraren med lämplig aga. ${ }^{82}$
}

Villkoren för att använda kroppsaga som bestraffningsåtgärd i Degebergas reglemente utvecklades i flera led. För det första handlade det om förseelsens art: smärre brister i uppförande ledde till förmaningar eller nedflyttning; brister av mer allvarlig art, såsom liknöjdhet, försumlighet, oordentlighet och uppstudsighet, ledde till all-

76 Exempelvis Reglemente för folkundervisningen inom Acklinga skoldistrikt (Skara, 1899), 9; Reglemente för folkundervisningen inom Baltacks skoldistrikt (Skara, 1899), 9. Reglementen med denna formulering återfinns enbart i Skara stift.

77 Reglemente för skolorna inom Brunskogs skoldistrikt (Karlstad, 1887), 10.

78 "Protokoll hållet vid skolrådssammanträde i Farstorps sockenstuga den 13 september 1885," 9. Se även Reglemente för Eskilstuna stadsförsamlings skolor (Eskilstuna, 1886), 4.

79 Folkskolereglemente för Gäfle stads församlings skolor (Gävle, 1894), 16.

80 Reglemente för Göteborgs stads folkskolor (Göteborg, 1899), 15.

81 Reglemente för folkskolor och småskolor $i$ Gråmantorps skoldistrikt (Helsingborg, 1888), 11.

82 Reglemente för såväl folkskola som småskola inom Degebergas skoldistrikt, Lunds stift (Kristianstad, 1891), 4. 
varligare konsekvenser. För det andra handlade det om frekvens: brister i uppförande som inträffade någon enstaka gång ledde till förmaningar eller nedflyttning, medan upprepning ledde till hårdare bestraffning. För det tredje tolkar jag paragrafen som att kroppsaga villkorades av att skolrådets ordförande skulle bedöma de använda tillrättavisnings- och bestraffningsformernas effekter, innan kroppsaga kunde tillgripas. Det bör också noteras att ordet kroppsaga inte nämns, men i sammanhanget framgår det att just den agaformen inbegreps i begreppet "lämplig aga".

Den abstraktion över korrektionsformer i folkskolereglementen 1882-1900, som presenterades i tabell 1, kan tillämpas också med hänsyn tagen till relationen mellan förseelsernas art och korrektionsformens natur. Görs denna tillämpning på Degebergas föreskrifter och hur ordningen skulle upprätthållas får man följande abstraktion.

Tabell 2. Abstraktion över korrelation mellan förseelse och korrektionsformer i Degeberga skoldistrikt.

\begin{tabular}{|l|l|l|l|}
\hline $\begin{array}{l}\text { Förseelseslag i Degebergas } \\
\text { skolor }\end{array}$ & \multicolumn{2}{|l|}{ Agaformer i sekvensslag } & $\begin{array}{l}\text { Degebergas konsekvens- } \\
\text { schema }\end{array}$ \\
\hline & Korrektionsform tillrättavisning & \\
\hline \multirow{2}{*}{$\begin{array}{l}\text { Brist i uppmärksamhet, flit } \\
\text { och ordning }\end{array}$} & \multirow{2}{*}{$\begin{array}{l}\text { Första åtgärds- } \\
\text { moment }\end{array}$} & I första rum & Förmaning \\
\cline { 3 - 4 } & I andra rum & Nedflyttning \\
\hline & Korrektionsform bestraffning & \\
\hline \multirow{2}{*}{$\begin{array}{l}\text { Oavlåtlig liknöjdhet; uppre- } \\
\text { pad försumlighet, oordent- } \\
\text { lighet eller uppstudsighet }\end{array}$} & \multirow{2}{*}{$\begin{array}{l}\text { Andra åtgärds- } \\
\text { moment }\end{array}$} & I tredje rum & Ytterligare varning \\
\cline { 3 - 4 } & & I fjärde rum & Längre tids nedflyttning \\
\cline { 3 - 4 } & I femte rum & \\
\cline { 2 - 4 } & I sjätte rum & \\
\hline Ej uppvisad förbättring & $\begin{array}{l}\text { Tredje åtgärds- } \\
\text { moment }\end{array}$ & I sjunde rum & Lämplig aga \\
\hline
\end{tabular}

Denna typ av abstraktion, som knyter samman förseelsens art med korrektionsformens natur, kan naturligtvis göras på de fyra konsekvensschemana som jag diskuterat ovan. Det behöver dock inte ytterligare åskådliggöras i tabellform, utan de mönster som föreskrifterna i Degeberga illustrerar är allmängiltiga: mindre förseelser, såsom lättja, olydnad med mera, reglerades av korrektionsformer som diskuterades i första åtgärdsmomentet; upprepade förseelser reglerades med korrektionsformer i andra åtgärdsmomentet; samt svårare och ytterligare upprepade förseelser reglerades med kroppsaga. I Degebergas föreskrifter omnämndes inte det fjärde åtgärdsmomentet (det vill säga "annan åtgärd"). Den åtgärden korrelerade utan undantag med uppvisad oförbätterlighet, "gröfre förbrytelser" eller att "genom vanart och dåligt uppförande utöfva ett skadligt inflytande på sina kamrater". ${ }^{83}$

\section{Föreskrifter om ordningens upprätthållande i reglementen före 1882}

De modeller som skapats för att analysera föreskrifter i folkskolereglementen om ordningens upprätthållande under 1880-talet och 1890-talet kan också användas på föreskrifter från en tidigare tidsperiod. Möjligheter att utläsa mönster på det sätt

83 Exempelvis Reglemente för folkskolor och småskolor i Augerums församling af Lunds stift (Karlskrona, 1885), 10. 
som diskuterats ovan är emellertid svårare. Det beror i sin tur på två saker. För det första är tryckta reglementen från denna tid mindre vanligt förekommande, vilket försvårar generaliseringsanspråk (se tabell 3). För det andra finns det större inbördes skillnader mellan reglementenas föreskrifter, vilket i sig gör det svårt att hänföra enskilda föreskrifter till urskiljbara generella korrektionsmodeller.

\section{Tabell 3. Antal tryckta reglementen 1842-1882 (baserat på tryckår)}

\begin{tabular}{l|l} 
Tryckår & Antal \\
\hline $1842-1849$ & 2 \\
$1850-1859$ & 2 \\
$1860-1869$ & 9 \\
$1870-1879$ & 12 \\
$1880-1882$ & 25
\end{tabular}

Källa: Tryckta folkskolerelementen 1842-1882, okatalogiserat tryck inom magasinsuppställning "Undervisning/Skolv./Folkskole reglementen", Uppsala universitetsbibliotek.

Vad man kan utläsa i tabell 3 är att skolreglementen sällan trycktes i större omfattning förrän under 1880-talet. Jag har alltså bara kunnat undersöka en mindre del av alla reglementen som fanns under denna period.

Några generella iakttagelser kan dock göras med utgångspunkt i detta material. De reglementen som utkom från och med 1870-talets sista hälft och under 1880-talets första år uppvisar stor överensstämmelse med de reglementen som trycks efter 1882 års folkskolestadga.$^{84}$ Det förefaller inte vara så att folkskolestadgan 1882 förde med sig revisioner och omformuleringar i föreskrifterna om ordningens upprätthållande, vilket min periodisering på ett sätt förutsatte. De reglementen som utkom från mitten av 1870-talet faller alltså, i allt väsentligt, in i de mönster som diskuterats i tidigare avsnitt. Vad som skiljer denna grupp reglementen från de som utkom efter 1882 är att i den förra gruppen reglementen saknar flertalet utmejslade sekvensslag av den sort som analyserats utifrån tabell 1. Flera reglementen skiljde inte mellan korrektionsformerna tillrättavisning och bestraffning. ${ }^{85}$ Det för med sig att flera reglementen inte heller åtskilde fyra åtgärdsmoment; men samtliga laborerade dock med minst två sådana och i de fall blott två omnämns så handlade det om, å ena sidan åtgärder som läraren själv kunde utföra, och å andra sidan åtgärder som lämnades över till skolrådet. ${ }^{86}$ Med andra ord åtskiljer dessa reglementen bara första och färde åtgärdsmomentet. Emellertid finner man också några reglementen som laborerade med fyra åtgärdsmoment. ${ }^{87}$ Vad gäller konkreta åtgärder föreskrev reglementena sådana som behandlats tidigare och i den stegrande ordning från varning och tilltal till kroppsbestraffning som redan diskuterats. Den enda avvikande bestraffningen som påträffats är ifrån Gräsö skoldistrikt, där "skamstraff” påtalades i tredje åtgärdsrum. ${ }^{88}$

84 Exempelvis Reglemente för skolorna i Borgviks skoldistrikt (Karlstad, 1881), 10.

85 Exempelvis Reglemente för folkskoleundervisningen i Garpenbergs församling af Westerås stift (Hedemora, 1872), 15; Reglemente för Fridlefstads församlings folkskolor (Karlskrona, 1875), 8-9; Reglemente för Efveröds församlings skolor (Lund, 1877), 6. Detta sekvensslag finns dock i vissa reglementen: exempelvis Reglemente för folkundervisningen i Bollnäs pastorat af erkestiftet (Söderhamn, 1871), s 14-15 och Reglemente för Gräsö församlings folkskolor (Stockholm, 1881), 11. I det sistnämnda reglementet skiljer man mellan att "rätta" och att "bestraffa".

86 Exempelvis Reglemente för Efveröds församlings skolor (Lund, 1877), 6.

87 Exempelvis Reglemente för skolorna inom Gåsborns socken (Filipstad, 1881), 11.

88 Reglemente för Gräsö församlings folkskolor (Stockholm, 1881), 11. 
Den tidigaste gruppen reglementen, med tryckår från 1842 till 1870, uppvisar flera påtagliga skillnader både i förhållande till gruppen reglementen under 1870-talet fram till 1882 och till den grupp reglementen som trycktes 1882 eller senare. Skillnaderna berör flera västenliga aspekter av de frågeställningar som den här artikel behandlar. För att kunna jämföra de tidiga reglementena från de senare behöver man beakta att de förra är mer omfångsrika. Relativt detaljerade textpartier behandlar skolstyrelsens uppgifter, läsordningar, undervisningsinnehåll och undervisningsmetoder, lärarens åligganden och skolkassan, vilket reglementen från 1870-talet och framåt generellt saknar. Den skillnaden kan naturligtvis förklaras genom att beakta att de tidiga reglementena reglerade en undervisningsverksamhet som i flera skoldistrikt var ny. Reglementena satte helt enkelt upp reglerande ramar för en omfattande organisation som inte funnits tidigare. Skolråden passade också på att kommunicera folkskolans värde och existensberättigande till församlingsborna genom reglementena. Rimligen förelåg inte sådana behov under 1870-talet och framåt, eftersom de reglerande ramarna för folkskolan då var etablerade och verksamheten knappast kunde ifrågasättas. Sammantaget gör detta att de språkligt väl broderade reglementena från den tidigare perioden, både inbördes och i jämförelse med senare reglementen, uppvisar stora skillnader gentemot varandra.

Den textmässiga relativa omfångsrikedomen avspeglas dock inte i föreskrifterna om hur ordning och disciplin skulle upprätthållas i folkskolorna. Just dessa textpartier är kortfattade, medan andra närliggande textpassader är mer utförliga. Måhända förutsäger detta förhållande ett annat sätt att resonera om upprätthållandet av ordning under den tidigare perioden jämfört med den senare, och som utförligare behöver beskrivas. Föreskrifterna i Borgviks skoldistrikt kan exemplifiera resonemangen:

Lärare skall på det noggrannaste vaka öfver barnens gudsfruktan, seder och uppförande, och om hos något barn finner osannfärdighet, oärlighet, olydnad eller annan vanart, med allvar förmana det samt genom föreställning söka på ett kärleksfullt sätt leda det felande barnet till rätta: hjälper icke föreställningen, må läraren använda lindrig aga. För övrigt skall skolläraren, till upplysning för Skol-Rådet samt föräldrar och målsmän, noga anteckna i Examens-Katalogen såväl barnens uppförande, som deras ådalagda flit under Skol-Terminen. ${ }^{89}$

Exemplet från Borgviks skoldistrikt innehåller flera skillnader i förhållande till senare reglementen. Jag vill utifrån detta exempel upplysa om fyra betydande skillnader. För det första ålades eleverna ge akt på andra slags uppförandenormer än vad senare reglementen gjorde (jämför Degebergas reglemente ovan). De tidiga reglementena betonade vikten av gudsfruktan, ${ }^{90}$ sannfärdighet, ${ }^{91}$ dygd,${ }^{92}$ laglydnad, ${ }^{93}$ undergivenhet, ${ }^{94}$ och liknande seder, medan senare reglementen påtalade vikten av flit, ord-

89 Exempelvis Reglemente för skolorna i Borgviks skoldistrikt (Karlstad, 1881), 10.

90 Exempelvis Reglemente för folkskoleinrättningen inom Fellingsbro församling (utan tryckort, 1846), 10; Projekt till reglemente för fyra ambulerande folkskolor inom Fernebo församling (Karlstad, 1851), 6.

91 Exempelvis Reglemente för Gåsborns folkskolor (Stockholm, 1844), 11.

92 Ibid.

93 Exempelvis Reglemente för folkskoleinrättningen inom Fellingsbro församling ([utan tryckort], 1846), 10; Reglemente för folkskolorna inom Folkerna församling (Falun, 1863), 14.

94 Reglemente för folkskolorna inom Folkerna församling (Falun, 1863), 14. 
ning och god inställning till skolarbetet. I detta avseende är de tidiga reglementena mycket omsorgsfulla när det kommer till att beskriva de goda sedernas nytta, vilket framkommer tydligt i reglementet från Gåsborns skoldistrikt:

Han [läraren] uppmuntre med förmaningar - till sanning, ty den är skön, - till dygd,
ty den är täckelig inför Gud och menniskor, - till flit, ty den öfvar själen och skapar
nytt lif, - till ordning, ty den är oumbärlig och nyttig till alla häraf. Han tillse, att intet
sjelfsvåld, i något hänseende får inrita sig, ty onda seder i en skola, äro ett frätande sår,
en kräfta på hvarje ditkommande, ny, ännu frisk lefvande lem. ${ }^{95}$

Utifrån Borgviks reglemente kan man också notera de relativt få konkreta åtgärdsmedel som läraren hade att förfoga över, nämligen förmaningar, föreställningar och kroppsaga. Några reglementen nämner inga åtgärdsmedel över huvud taget. ${ }^{96}$ Andra föreskriver någon strafform med exemplifieringar, men utan den sekvensordning som vi känner igen från senare reglementen. ${ }^{97}$

I Borgviks reglemente kan man för det tredje notera en uppmaning till läraren att samverka med skolrådet och målsmännen ifråga om elevernas uppförande. Denna uppmaning, menar jag, är ett exempel på en mer genomgripande föreställning om att upprätthållandet av ordningen i skolan också var av utominstitutionell karaktär, vilket i mindre grad förekom i senare reglementen. De utominstitutionella medlen för att upprätthålla ordning kan i sin tur brytas ned i två arenor där korrektionen utfördes, nämligen i hemmen och i det offentliga, samt två - med dessa arenor korresponderande - auktoriteter som utförde korrektionen, nämligen föräldern och kyrkans representanter. Ordalydelsen i Borgviks reglemente är ett exempel på den förra typen (i hemmen och av föräldern). Den tidiga gruppen reglementen betonade vikten av att läraren löpande noterade "hvaje barns verkliga förseelse, såsom sen ankomst osnygghet, oskick, olydnad, bristande lexöfverläsning, lögnaktighet o. s. v."98 i en anmärkningsbok, vilken vid varje veckoslut kom föräldrarna till del för att på så sätt "sätta dem i stånd att samverka med [s]kolläraren uti både föreställning och uppmuntran”. ${ }^{99}$ Föräldrarna förväntades foga sin underskrift till noteringarna för att påvisa sin delaktighet i kommunikationsakten mellan hem och skola. ${ }^{100}$

Den andra typen av utominstitutionella medel för att upprätthålla ordning var att offentligen kommunicera brister i elevernas uppförande. Det kunde ske i två sammanhang: från predikstolen om söndagen och/eller under examensdagen vid terminens slut. Examen var offentlig, men riktade sig särskilt till barnens målsmän. Under denna skulle [d]en, som flere gånger under samma termin utan tillstånd eller förfall varit frånvarande, eller visat större eller fortfarande lättja, osedlighet eller oordentlighet, erhålle [...] varningar av [s]kolrådets ordförande". ${ }^{101}$ Sammantaget var alltså

95 Reglemente för Gåsborns folkskolor (Stockholm, 1844), 11.

96 Exempelvis Reglemente för Gåsborns folkskolor (Stockholm, 1844); Reglemente för folk- och småbarnsskolorna i Filipstads och Fernebo församlingar (Filipstad, 1864).

97 Exempelvis Reglemente för folkskolan i Dalby socken (Karlstad, 1865), 10. Detta reglemente föreskrev "moraliska straff, t. ex. att få stå medan andra sitta, mista lekstunder o. s. v.".

98 Reglemente för folkskolan i Dalby socken (Karlstad, 1865), 10.

99 Reglemente för skolorna i Borgviks församling (Karlstad, 1866), 4.

100 Exempelvis Reglemente för folkskolan i Fryksände församling (Karlstad, 1870), 15.

101 Reglemente för folkskoleundervisningen i Falu stad af Westerås stift (Falun, 1866), 14. Se även Reglemente för folkskoleinrättningen inom Fellingsbro församling (utan tryckort, 1846), 10; Reglemente för folkskolorna inom Folkerna församling (Falun, 1863), 14. 
utominstitutionella uppfostringsmiljöer, och de medel för att upprätthålla ordning som dessa härbärgerade, synliggjorda i de tidiga reglementena som saknar motsvarighet i de senare. ${ }^{102}$

Karaktäristiskt för de tidiga reglementena är för det fjärde att åtgärdsmomenten som vi känner dem från reglementen från 1800-talets två sista decennier i stort sett saknas i de tidiga reglementena. Olika tillrättavisnings- och bestraffningsformer separeras inte i sekvenser, med tillhörande ökad allvarlighetsgrad efter förseelsens natur. Särskilt bör man uppmärksamma att det färde åtgärdsmomentet i de senare reglementena (annan åtgärd) sammansmälte med tidigare moment och de medel som tillhör dessa. Medlen för upprätthållandet av ordningen utförda av läraren i skolan kompletterades av åtgärder utanför skolan. Det är slutsatsen man måste dra om modellen i tabell 1 tillämpas på de tidiga reglementena.

Slutligen vill jag uppmärksamma de tidiga reglementenas föreskrifter om kroppsbestraffning. En relativ stor andel av de tryckta reglementena från 1842 till 1870 föreskriver inskränkningar i lärarens rätt att kroppsligen bestraffa eleverna. I reglementet från exempelvis Fryksände skoldistrikt påtalades att vid kroppsbestraffningar fick läraren inte "[...] gå tillväga med hetsighet eller oförstånd” och ytterligare preciseringar sade att "[b]arnens hufvud făr vid aga ej vidröras utan endast dess minst ömtåliga kroppsdelar, dock äfven dessa med varsamhet." ${ }^{103}$ I ett antal skoldistrikt var läraren tvungen att överskjuta kroppsbestraffningar till skolrådet. ${ }^{104}$ Några reglementen är svårtolkade på den punkten eftersom de inte över huvud taget nämner kroppsbestraffning som korrektionsmedel. ${ }^{105} \mathrm{Om}$ det i sin tur beror på att åtgärden var för självklar för att nämnas eller om det betydde att kroppsaga inte fick förekomma går inte att uttala sig om utifrån materialet. ${ }^{106}$

\section{Sammanfattande diskussion}

Stora delar av den här undersökningen har ägnats åt att presentera och diskutera aspekter av en modell framtagen för att systematiskt undersöka mönster i hur 1800-talets folkskolereglementen uttryckte åtgärder för att upprätthålla ordning i skolan. Modellen är i sin tur en abstraktion av alla tryckta folkskolereglementen i Sverige under 1800-talet. Sammanfattningsvis skall jag belysa några centrala resultat som modellen hjälpt till att identifiera.

Folkskolereglementena utvecklades successivt mot en mer detaljerad sekvenslista av åtgärder som läraren kunde vidta för att upprätthålla ordningen i klassrummen. Brytpunkten för den utvecklingen kan härledas till slutet av 1870-talet och början av

102 Jag har bara funnit orden målsman eller föräldrar i tre reglementen efter 1882 .

103 Reglemente för folkskolan i Fryksände församling (Karlstad, 1870), 15. Se även Reglemente för Brunnby skolor (utan tryckort, 1870), 5.

104 Reglemente för folkskolorna $i$ Grava församling (Karlstad, 1868), 13; Reglemente för folkskolan $i$ Dalby socken (Karlstad, 1865), 10; Reglemente för folkskolorna inom Askersunds landsförsamling (Askersund, 1868), 9. Från Askersund finns ett reviderat reglemente från 1888. I det senare ges läraren rätten att utdela kroppsaga.

105 Exempelvis Reglemente för Gåsborns folkskolor (Stockholm, 1844); Reglemente för folk- och småbarnsskolorna $i$ Filipstad och Fernebo församlingar (Filipstad, 1864); Reglemente för folkskolorna $i$ Grava församling (Karlstad, 1868).

106 Från Gåsborns församling finns reglementen från 1844 och 1880 och från Grava församling från 1868 och 1881. Det är blott i de senare som lindrigare aga påtalas som bestraffningsmedel. Utifrån reglementenas ordalydelse tillkom alltså kroppsbestraffningar som bestraffningsmedel i dessa församlingar. 
1880-talet. Den innebar en utveckling till ett slags standard där fyra åtgärdsmoment utkristalliserades i reglementena. Det första åtgärdsmomentet handlade om att genom kärleksfullt tilltal, förmaningar och/eller varning korrigera oönskade beteenden. Det andra åtgärdsmomentet handlade om mer kännbara bestraffande åtgärder av mer olikartade slag. Först som tredje åtgärsmomentet kunde kroppsaga förekomma i lindrigare form eller i form som stod i proportion till förseelsens allvarsgrad. I det fjärde åtgärsmomentet kunde skolrådets ordförande diskutera andra åtgärder i samråd med läraren. Analysmodellen har visat att skillnader existerade i hur skoldistriktens reglementen uttryckte de korrektionsmedel som stod till förfogande och i vilka sammanhang de skulle användas. För att upptäcka dessa skillnader sammanförde undersökningen identiska reglementen till fyra huvudgrupper (i artikeln kallat konsekvensscheman).

Det som i första hand skiljde dessa grupper av reglementen åt, var vilka typer av åtgärder som omnämndes i andra åtgärdsmomentet. En grupp av reglementen uttryckte bara ett slags åtgärd i det andra åtgärdsmomentet, medan en annan grupp reglementen uttryckte fyra åtgärdsformer. I den senare gruppen återfanns en påtagligt större variationsbredd av bestraffningar, som bland annat inbegrep den felande elevens förflyttning i det fysiska ordnade klassrummet efter kunskaps- och uppförandebaserad hierarki samt åtgärder i syfte att framkalla blygsel och ånger hos den felande eleven. Just det andra åtgärdsmomentet uttrycker kvardröjande pluralitetstendenser i ett annars allt mer homogeniserat system för att uttrycka de åtgärder läraren hade till förfogande för att upprätthålla ordning. I det andra åtgärdsmomentet, som kan beskrivas som en "buffert" mellan det kärleksfulla tilltalet och den kroppsliga bestraffningen, fanns det utrymme, och i någon mån friheter, för skoldistrikten att utveckla nya och bibehålla äldre bestraffningstekniker. I momentet återfanns sedan länge beprövade bestraffningsformer (som nedflyttning) och bestraffningsformer som hade sitt ursprung från en mer näraliggande tid (anmärkning i bok). "Bufferten" mellan det kärleksfulla tilltalet och den kroppsliga bestraffningen fylldes med åtgärder som kunde väcka olika former av olustkänslor hos eleverna. En del åtgärder, som att anvisa någon till avskild plats eller att förflytta en elev i klassrummet, syftade till att störa den fysiska och mentala känslan av gemenskap och tillhörighet som fanns i elevgruppen. Andra åtgärder, som att låta någon resa sig och förbli stående, väckte antagligen fysiska obehag om det pågick tillräckligt länge eller ofta.

Åtgärdsmomenten kan också användas för att förstå korrelationsmönster mellan förseelser och de konsekvenser som förseelsen medförde. Mönstret består i att mindre förseelser som slarv, bristande uppmärksamhet och enstaka uttryck av brist i ordning medförde åtgärder inom ramen för det första åtgärdsmomentet. Först vid upprepning av sådana beteenden skulle åtgärder i det andra momentet komma ifråga. Skiljelinjen mellan dessa förseelseslag tycks ha gått vid elevernas egna insikter i och medvetenhet om felande handlingar. Felande handlingar av slarv, obetänksamhet eller okunskap tillhörde det första åtgärdsmomentet, felande handlingar som gjordes mot bättre vetande, överlagt eller med avsikt bestraffades med åtgärder i det andra åtgärdsmomentet.

Analysmodellen har också identifierat några andra påtagliga förändringar över tid. Om man beaktar enbart hur reglementena uttrycker upprätthållandet av ordning i skolan faller de ut i tre kronologiska grupper. Den kronologiskt senare gruppen reglementen, från 1882-1900, har fasta former, lättidentifierade mönster vad 
gäller agaformernas sekvenser och förändras egentligen inte alls under denna period. Den kronologiskt tidiga gruppen reglementen, från 1842 till 1870, är mer omfångsrika, saknar fasta former för hur bestraffningens sekvenser uttrycks och påtalar generellt färre tillrättavisnings- och bestraffningsåtgärder än senare reglementen. Den kronologiskt mellanliggande perioden, 1870 till 1882, bildar en egen grupp reglementen som kännetecknas av ökande grad av den enhetlighet som utmärker den senare gruppen. Jämför man den tidiga gruppen reglementen med den senare kan flera intressanta iakttagelser göras. Den mest påtagliga skillnaden är att de tidiga reglementena påtalar vikten av kontakter mellan skolan och utominstitutionella uppfostringsmiljöer i syfte att upprätthåla ordning i skolan.

Dessa utominstitutionella miljöer, som skolan kommunicerade uppförandenormer med, återfanns på två arenor: i hemmet och i det offentliga församlingslivet. Hemmen underrättades löpande om barnens uppförande i skolan och förutsattes påverka densamma. Ifrån predikstolen och under offentliga examens- och förhörsövningar offentliggjorde prästerskapet eller läraren individuellt elevernas filt, ordningssamhet och sedlighet. Uttryck för att löpande använda dessa kanaler och uppfostringsmedel saknas i den senare gruppen reglementen. Min tolkning av att dessa utominstitutionella uppfostringsmiljöer betonades i den tidiga gruppen reglementen är att de också avspeglade en föreställning om elevernas uppförande som en kollektiv, offentlig angelägenhet. Denna uppfattning förändras under 1870-talet och då knöts i stället uppförandefrågor i skolan exklusivt till läraren. De offentligt uppvisade försyndelserna - och de skam- och olustkänslor i form av försvagat anseende som säkert föreställningarna utmynnade i - försvann successivt under 1800-talets sista decennier. Denna förändring var, enligt min mening, sammanflätad med att uppförandenormerna i folkskolan förändrades. Av vad man kan utläsa i de tidiga reglementenas föreskrifter betonades uppförandenormer som gudsfruktan, sedlighet, undergivenhet, sannfärdighet och laglighet. Det var också på grund av uppvisade brister ifråga om dessa uppförandenormer som eleverna skulle tillrättavisas eller bestraffas. I den senare gruppen reglementen var det andra typer av brister, såsom ouppmärksamhet, oordning, bristande flit, liknöjdhet, lättja och uppstudsighet som tillrättavisningarna och bestraffningarna var tänkta att beivra. Häri ligger naturligtvis ett intressant samband. De uppförandenormer som framhölls i den tidiga gruppen reglementen var sådana som ansågs betydelsefulla i livet i stort, vilket för med sig att tillsynskretsen var vidare. Däremot var uppförandenormerna i den senare gruppen reglementen mer specifika i förhållande till skolans egen verksamhet och därmed institutionaliserades upprätthållandet av ordningen. 


\section{Referenser}

\section{Tryckta källor}

Folkskolereglementen i urval 1842-1900: Okatalogiserat tryck inom magasinsuppställning, "Undervisning /Skolv./ Folkskole reglementen" (Universitetsbiblioteket i Uppsala, kapsel 1-50).

Kongl. Maj:ts nådiga stadga angående folkundervisningen i riket: Gifwen Stockholoms slott den 18 juni 1842. (Folkskolestadgan 1842).

Kongl. Maj:ts förnyade nådiga stadga angående folkundervisningen i riket: Gifwen Stockholoms slott den 20 januari 1882. (Folkskolestadgan 1882).

Kongl. Maj:ts förnyade nådiga stadga angående folkundervisningen i riket: Gifwen Stockholoms slott den 10 december 1897.

(Folkskolestadgan 1897).

Nationalencyklopedin.

Svenska Akademiens ordbok (SAOB).

Svenska Akademiens ordlista (SAOL), upplaga 14.

\section{Internetkällor}

Anmärkningsbok år 1859 för Carl Fr. Erdmann uti 1 klassen af nya elementarskolan $i$ Stockholm. Stockholmskällan: https://stockholmskallan.stockholm.se/ post/28106.

\section{Litteratur}

Bergenlöv, Eva. Skuld och skam: Barnamord och barnkvävning i rättslig diskurs och praxis omkring 1680-1800. Lund: Historiska institutionen, 2004.

Bergenlöv, Eva. Drabbade barn: Aga och barnmisshandel i Sverige från reformation till nutid. Lund: Nordic Academic Press, 2009.

Berglund, Tomas. Det goda faderskapet i svenskt 1800-tal. Falun: Carlsson, 2007.

Brembeck, Helena. Tyst, lydig, arbetsam: Om barnuppfostran på den västsvenska landsbygden. Göteborg: Etnologiska föreningen i Västsverige, 1986.

Brockliss, Laurence och Montgomery, Heather. "Preface." I Childhood and Violence in the Western Tradition, redaktör Laurence Brockliss och Heather Montgomery, ix-xvi. Oxford: Oxbow books, 2010.

Curtice, Bruce. "'My Ladie Birchely must needed rules': Punishment and the Materialization of moral character from Mulcaster to Lancaster." I Discipline, Moral Regulation, and Schooling: A Social History, redaktör Kate Rousmaniere, Kari Dehli och Ning de Coninck-Smith, 19-43. New York: Garland Publishing, 1997.

Ellis, Heather. "Corporal Punishment in the English Public School in the Nineteenth Century." I Childhood and Violence in the Western Tradition, redaktör Laurence Brockliss och Heather Montgomery, 113-22. Oxford: Oxbow Books, 2010.

Florin, Christina och Ulla Johansson. "Three Cultures, Three Stories: Discipline in Grammar School, Private Girls' School and Elementary Schools in Sweden, 1850-1900. I Discipline, Moral Regulation, and Schooling: A Social History, redaktör Kate Rousmaniere, Kari Dehli och Ning de Coninck-Smith, 43-73. New York: Garland Publishing, 1997.

Herman, Frederik, Marc Depaepe, Frank Simon och Angelo Van Gorp. "Punishment as an Educational Technology: A Form of Pedagogical Inertia in Schools?" I Educational Research: Networks and Technologies, redaktör Paul Smeyers och Marc Depaepe, 203-19. New York: Springer, 2007. 
Heywood, Colin. Growing up in France: From the Ancien Régime to the Third Republic. Cambridge: Cambridge University Press, 2007.

Hogan, David. "The market revolution and disciplinary power: Joseph Lancaster and the psychology of the early classroom system." History of Education Quarterly 29, no. 3 (1983), 381-417.

Humphries, Jane. Childhood and Child Labour in the British Industrial Revolution. Cambridge: Cambridge University Press, 2010.

Humphries, Jane. "Childhood and Violence in Working-Class England 1899-1870." I Childhood and Violence in the Western Tradition, redaktör Laurence Brockliss och Heather Montgomery, 135-41. Oxford: Oxbow books, 2010.

Landahl, Joakim. "The Eye of Power(-lessness): On the Emergence of the Panoptical and Synoptical Classroom." History of Education 26, no. 6 (2013), 803-21.

Larsson, Esbjörn. En lycklig Mechanism: Olika aspekter av växelundervisningen som en del av 1800-talets utbildningsrevolution. Uppsala: Opuscula Historica Upsaliensia, 2014.

Liliequist, Marianne. Nybyggarbarn: Barnuppfostran bland nybyggare i Frostvikens, Vilhelmina och Tärna socknar 1850-1920. Umeå: Acta Universitatis Umensis, 1994.

Lindstedt Cronberg, Marie. Med våldsam hand: Hustrumisshandel i 1800-talets Sverige: En studie av rättsliga, kyrkliga och politiska sammanhang. Lund: Lunds universitet, 2009.

Lindstedt Cronberg, Marie. "Husbondeväldets undergång: Retoriken och metaforiken i 1800-talets riksdagsdebatter." I Våld: Representation och verklighet, redaktör Eva Österberg och Marie Lindstedt Cronberg, 206-30. Lund: Nordic Acamdemic Press, 2015.

Margolis, Eric och Sheila Fram. "Caught Napping: Images of Surveillance, Discipline and Punishment on the Body of the Schoolchild." History of Education 36, no. 2 (2007), 191-211.

Mause, Llyod de, red. The History of Childhood: The Evolution of Parent-Child Relationship as a Factor in History. London: Souvenir press, 1977.

Mause, Llyod de, red. The History of Childhood: The Untold Story of Child Abuse. London: Bellow, 1991.

Mellberg, Margareta. Pedagogen och det skrivna ordet: Skrivkonst och folkskollärare 1870-1920. Göteborg: Göteborgs universitet, 1996.

Miralles, Carles Sirera. "Enlightened Paternalism: The Prohibition of Corporal Punishment in Spanish Public Schools in the Nineteenth Century." History of Education 44, no. 2 (2015), 156-70.

Norberg, Astrid. Uppfostran till underkastelse: En analys av normer för föräldra-barnrelationer i religiös litteratur om barnuppfostran i Sverige 1750-1809. Lund: Gleerup, 1978.

Norlin, Björn. "School Jailhouse: Discipline, Space and the Materiality of School Morale in Early-Modern Sweden." History of Education 45, no. 3 (2016), 263-84.

Ohlander, Ann-Sofie. Kärlek, död och frihet: Historiska uppsatser om människovärde och livsvillkor i Sverige. Stockholm: Nordstedts, 1985.

Ohlander, Ann-Sofie. Det bortträngda barnet: Uppsatser om psykoanalys och historia. Uppsala: Opuscula Historica Upsaliensia, 1993.

Ozment, Steven. When Fathers Ruled: Family Lift in Reformation Europe. Cambridge Mass.: Harvard University Press, 1983. 
Persson, Birgit. "Aga och husliga bestraffningar." I Den utsatta familien: Liv, arbete och samlevnad i olika nordiska miljöer under de senaste tvåhundra åren. En antologi från det Familjehistoriska projektet vid historiska institutionen, Uppsala universitet, redaktör Hans Norman. Stockholm: LT, 1983.

Pollock, Linda. Forgotten Children: Parent-Child Relations from 1500 to 1900. Cambridge: Cambridge University Press, 1983.

Rousmaniere, Kate, Kari Dehli och Ning de Coninck-Smith. "Conclusion: New Perspective on Moral Regulation and Schooling." I Discipline, Moral Regulation, and Schooling: A Social History, redaktör Kate Rousmaniere, Kari Dehli och Ning de Coninck-Smith, 273-77. New York: Garland Publishing, 1997.

Rousmaniere, Kate, Kari Dehli och Ning De Coninck-Smith. "Moral Regulation and Schooling: An Introduction." I Discipline, Moral Regulation, and Schooling: A Social History, redaktör Kate Rousmaniere, Kari Dehli och Ning De Coninck-Smith, 3-18. New York: Garland Publishing, 1997.

Sjögren, David. "Folkskollärare i konflikt med skolråd och allmoge 1840-1900.” I Nationen så in i Norden: En festskrift till Torkel Jansson, redaktör Henrik Edgren, Lars M Andersson, Urban Claesson och Bo G. Hall, 183-97. Skellefteå: Artos \& Norma Bokförlag, 2013.

Westberg, Johannes. Att bygga ett skolväsen: Folkskolans förutsättningar och framväxt 1840-1900. Lund: Nordic Academic Press, 2014.

Vinterek, Monika. Åldersblandning i skolan: Elevers erfarenheter. Umeå: Umeå universitet, 2001.

Österberg, Eva. Folk förr: Historiska essäer. Stockholm: Atlantis, 1995.

Österberg, Eva. "Barn i äldre tid - kulturhistoriska perspektiv." I Barnet i kyrkohistorien, redaktör Anders Jarlet, 21-33. Lund: Lund University Press, 1998. 